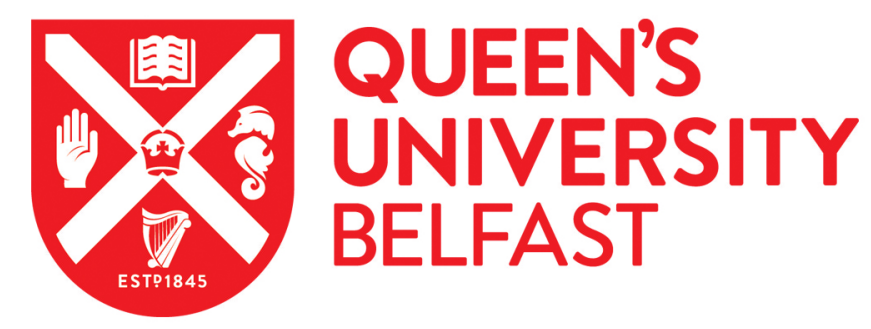

\title{
Locating historical Dún Bolg and the early medieval landscape of Baltinglass, Co. Wicklow
}

O’Driscoll, J., \& Gleeson, P. (2021). Locating historical Dún Bolg and the early medieval landscape of Baltinglass, Co. Wicklow. Royal Irish Academy. Proceedings. Section C: Archaeology, Celtic Studies, History, Linguistics and Literature, 121C, 91-124. https://doi.org/10.3318/priac.2021.121.03

Published in:

Royal Irish Academy. Proceedings. Section C: Archaeology, Celtic Studies, History, Linguistics and Literature

Document Version:

Peer reviewed version

Queen's University Belfast - Research Portal:

Link to publication record in Queen's University Belfast Research Portal

\section{General rights}

Copyright for the publications made accessible via the Queen's University Belfast Research Portal is retained by the author(s) and / or other copyright owners and it is a condition of accessing these publications that users recognise and abide by the legal requirements associated with these rights.

Take down policy

The Research Portal is Queen's institutional repository that provides access to Queen's research output. Every effort has been made to ensure that content in the Research Portal does not infringe any person's rights, or applicable UK laws. If you discover content in the Research Portal that you believe breaches copyright or violates any law, please contact openaccess@qub.ac.uk. 


\section{Authors and Affiliation:}

James O'Driscoll, University of Aberdeen,

St. Mary's, Elphinstone Road, Aberdeen,

AB24 3UF

+44 (0)1224 273693

James.odriscoll@abdn.ac.uk

Patrick Gleeson,

Queens University Belfast,

Fitzwilliam Street,

Belfast

+44 (0)2890973826

p.gleeson@qub.ac.uk 


\title{
Locating Historical Dún Bolg and the Early Medieval
}

\author{
Landscape of Baltinglass, Co. Wicklow.
}

\begin{abstract}
During the early medieval period around AD 400-1200, the Baltinglass landscape in eastern Ireland may be interpreted as a major central place connected with important regional dynasties like the Ui Cheinnselaig and latterly the Uí Máil. Its significance is explicitly recorded in historical sources such as the Bórama Laigen and Fingal Rónáin, as well as a number of annal entries, which refer to an important royal fortress in the area known as Dún Bolg. This fortress has been linked with a complex of enclosures on Spinans Hill, including a massive fort some 131ha in size, located a few kilometres to the east of Baltinglass. This, along with a number of previously unrecognised early medieval sites presented below, reveals a powerful and heavily mythologised landscape that was instrumental to dynasties emerging from the shadows of the Iron Age in central Leinster. This paper attempts to merge the rich historical tradition with the archaeological evidence to elucidate the broader importance of the Baltinglass landscape during the early medieval period.
\end{abstract}

\section{Introduction}

The Baltinglass landscape in Co. Wicklow is best known for the incredible group of Early Neolithic and Bronze Age enclosures that form some of the earliest and largest fortifications known in Ireland or Britain (O'Driscoll 2016; O'Brien and O'Driscoll 2017) (Figure 1). While this prehistoric landscape is one of considerable importance, there is also a significant early medieval element that has received less consideration. Historical sources refer to a major fortification in the area overlooking the Glen of Imaal, near Baltinglass, known as Dún Bolg, seat of Uí Chennseláig and latterly the Uí Máil. This 
important site has traditionally been associated with the large stone hillfort known as Brusslestown Ring, a few kilometres to the east of Baltinglass.

Dún Bolg enjoys a rich historical tradition, with major saga literature such as Fingal Rónáin (tenth century) and the Bórama Laigen (eleventh century) focused on the area. Dún Bolg is also referred to on a number of occasions in annals, and may appear in epithets of early kings via the synonym 'Bolg Lúatha'. Other key indicators of this landscapes importance include placenames like domnach, a toponym indicative of a conversion-period church; a series of newly identified cemetery settlements; a large burial mound (perhaps used for inauguration); and a concentration of prehistoric cemetery complexes. All of these elements are suggestive of a significant Late Iron Age/early medieval landscape, and potentially royal assembly functions focused on the Baltinglass region. This paper will address and contextualise this new information and access the broader importance of Baltinglass during the early medieval period.

\section{The Central Midlands Dynasties}

Leinster, as an ancient Irish province, occupied a special place in the real and imagined scheme of things in the Middle Ages, with the genealogies of some seventeen tribes and hundreds of septs transcribed by early Irish historians (Smyth 1982, 8-13). While we do not get a reliably detailed picture of the political geography here until approximately AD 800, Smyth $(1982,9-10)$ argues that the boundaries of the province and its many internal divisions likely remained somewhat fixed from approximately the sixth-twelfth centuries, making tentative territorial reconstructions possible (further MacCotter 2008, 131; 177-8).

During the fifth-seventh century, central Leinster is a shadowy region, with much historiography and political history focused on disentangling the details of geopolitics from later myth, as well as redacted and interpolated annals. A number of scholars, for instance, have argued that in the fifth 
century, Leinster was indeed a province, encompassing the Hill of Tara,Co. Meath, much of the midlands, and stretching as far north as the River Boyne (Byrne 1973; Bhreathnach 2005;

MacShamhráin 1996). Thomas Charles-Edwards $(2000,159 ; 2013,176)$ has argued that a Laginian polity also held territories in northern Wales during this period, a fact hinted at in the Bórama Laigen, which states Brandúb could levy rent and tribute in Britain (Stokes 1892, 57). While it seems unlikely that all of the major dynasties who emerge into contemporary history were indeed powerful in this pre-AD 600 period, it seems that much of northern Leinster and perhaps the midlands was controlled by a number of groups, possibly loosely confederated, who remained important, free peoples in later centuries: namely Dál Messin Corb, Uí Enechglais, Uí Bairrche and Uí Failge (Smyth 1974, 129-133; Gleeson and Ó Carragáin 2016). The pseudo-history of the fifth and sixth century is dominated by the struggle for control of the midlands and northern Leinster (see Smyth 1972), with these groups attempting to hold the advances of early Uí Néill dynasties (Charles-Edwards 2000, 441-68). Whatever weight one places in the historicity of these narratives, by around AD 600, the geopolitical dynamics of northern Leinster had shifted dramatically, with the rising Uí Dunláinge and Uí Chennseláig coming to respectively dominate the northern and southern regions of the province. How these dynasties emerged, and what exactly their relationship to each other was, has proved difficult to elucidate. The dominance of these dynasties in later centuries, however, mean that much of Leinster's early history as related in sagas and annals has been mediated as propaganda, with genealogies being wholly re-fashioned to accord with contemporary political needs on a number of occasions (MacShamráin 1996). Despite this, it would appear that there is relatively reliable evidence that the central region of Leinster, an area around Baltinglass in particular, was a major centre of royal power, albeit controlled by various groups throughout the period.

Dál Messin Corb apparently ruled much of the Liffey Plain in central Kildare during the fifth century before being driven to the Wicklow coast by the seventh century (Smyth 1982, 17). By the seventh century at the latest, they would appear to have lost their pre-eminent position in north-central Leinster to the Uí Máil (Cualu area of south Co. Dublin) and Uí Dúnlainge (central Kildare: 
Mullaghmast northwards to Lyons Hill), and in the lands east and south of the Wicklow Mountains to both the latter and Uí Chennseláig (Smyth 1982 14-17; 80). Uí Dúnlainge's rise saw a focus emerge during the seventh century east of Kildare, centred on Dún Ailinne and Óenach Carmain, the symbolic 'provincial' heart of Leinster (Swift 2006, 113; Gleeson and Ó Caragáin 2016). It is clear from historical sources that other major regional centres of power existed prior to this, with, for instance, Lyon's Hill, Killiney, Delgany or Naas, in north-central Leinster. Further south, Dún Bolg would appear to have been a major fortress associated with the Uí Cheinnselaig and Uí Máil when each were at the height of their powers, from at least the late sixth century.

There are two important references to Dún Bolg in the annals as well as a number of other references that may refer to the same place. The first recounts a major battle at the site around AD 597, where Brandúb mac Eochu, head of Uí Cheinnselaig and king of Leinster, defeated Áed mac Ainmuire, king of the Uí Néill and perhaps king of Tara. A second major battle occurs at Dún Bolg around AD 870, again involving an Uí Néill king of Tara, Áed mac Níall, and the Osraige king, Cerball mac Dùngal. From the Annals of Ulster entry, it appears that Cerball led a Leinster force against Áed, who was camped at Dún Bolg. Given that in previous decades a number of Uí Néill kings led hostings against the Laigin that involved camping at ancient royal seats (e.g. Dún Ailinne), this entry may imply a continuing symbolic importance and political significance for Dún Bolg (see Swift 2006, 1522 for discussion). Semple $(2013,87)$ notes the 1006 entry in the Anglo Saxon Chronicle which implies that a force might encamp at a site as a challenge, inviting the opposition to meet them at a specific landmark, and we might interpret entries in Irish sources in a similar manner.

Dún Bolg might also be identified as Bolg Lúatha (Smyth 1994, 79-80) mentioned a number of times in historical texts and placed in the same central midlands area. Bolg Lúatha is an epithet attached to one Crunnmáel Bolg Lúatha, whose son, Colgu, is described as king of Uí Chennseláig in AU647.3. Considering that this hints at an Uí Chennseláig link that agrees with the earlier affiliation of Brandúb in reference to Dún Bolg, it is suggestive that Crunnmáel Bolg Lúatha was also besieged by the Uí 
Néill in 626, probably at Dún Bolg (AU626.2). In 628 (AU628.1) the battle of Bolg Lúatha is recorded, in which the Uí Dunláinge king, Faelán mac Colmáin, was victor. Faelán was the progenitor of the Uí Faeláin lineages who controlled the kingdom around Dún Ailinne and Óenach Carmain and was apparently allied with segments of the southern Uí Néill against the Uí Failge of western Kildare and Co. Offaly (further Gleeson and Ó Carragáin 2016). Potentially, the 628 entry intimates a battle for supremacy in central Leinster between these rival dynasties. If so, and if this did take place at Dùn Bolg, then whether Dún Bolg was an Uí Chennseláig caput or not, this would imply a regional to supra-regional importance for the site that is also implicit in the entry for AU598.2. Similarly, the epithet of one Crunnmáel Erbuilg mac Rónán, who died as king of the Laigin in 656 (AU656.4) may also reference the same fortress and imply its status as dynastic, if not regional, caput.

The connection between Bolg Lúatha and Dún Bolg is not a certain one and relies on the shared element 'bolg' ('bag' or 'sack'). This is highlighted in the Annals of Tighernach (T630.1), which records Faelán's victory as taking place at the battle of Duma Aicher rather than Bolg Lúatha. However, here too we see hints that this may be referencing Dún Bolg/Bolg Lúatha, with the entry specifically stating that 'the battle of Duma Aichir [took place] by 'Bag of Ashes'. This was clearly an important place, given that Crunnmáel, who is described as 'Crunnmáel Bolg Lúatha' in the AU647.3 entry is earlier designated 'Sack of Ashes Crundmael, king of south Leinster' in T628.4. Similarly, AU626.2 records the attack by the Uí Néill as 'The besieging of Crunmael 'Sack of Ashes' by the Uí Néill'. A more explicit example is the M644.2 entry in the Annals of the Four Masters which notes the death of an Uí Chennseláig king; 'Bolgluatha, Lord of Ui Ceinnsealaigh, died', while the Annals of Tighernach (T648.2) record 'Sack of Ashes, king of Ui Cennselaigh, died'. Furthermore, the Metrical Dinnshenchas records the location Mag Luathat 'Plain of Ashes' (Stokes 1895, 304), linking the Lúatha element with ash. We might therefore tentatively consider the Duma Aicher of the T630.1 entry as another name for Bolg Lúatha/Dún Bolg. There are three entries referring to Duma Aichir in the Ulster Annals (AU468.2; 474.1; 476.1), two of which specifically mention the Laigin, and one in the Annals of Inshfallen (AI470.1). These are early references, suggesting this could be an early 
tradition, with the T630.1 entry the latest reference referring to Duma Aichir. If Duma Aichir can be linked with Dún Bolg it suggests an even earlier importance for the site.

Regardless of the difficulties of interpretation posed by these entries, they potentially reveal a connection between Dún Bolg, the most powerful dynasts in sixth and seventh century Leinster, and the Uí Néill, who were the major antagonists of the Laigin in this period (Smyth 1982, 52; Clinton 2000, 275). The attacks by the Uí Néill were a continuation of the hostility against the Uí Cheinnselaig (Smyth 1994, 80), a sept related to Brandúb's victory over the Uí Néill in AD 597. However, there was also a strategic and political reasoning for these assaults, with many of the above Uí Cheinnseláig kings also reputedly reigning as kings of Leinster and residing within or in close proximity to Dún Bolg. It is telling to note here, that whereas the Uí Dunláinge supremacy seems to have been based around Dún Ailinne, what evidence we do have would suggests that Dún Bolg served a similar purpose as a symbol of regional supremacy, albeit for Uí Chennseláig.

It was not until the rise of the Uí Dúnlainge in the eighth century, when they began to dominate a nascent kingship of Leinster (Ó Cróinín 2005, 199), that we see a notable absence of references to Dún Bolg and a de-escalation of tensions between the Uí Néill and the Laigin. The Uí Dúnlainge may have become a puppet institution sustained by the Uí Néill, an assumption supported by the fact that, when the Uí Máil briefly recovered supremacy around AD 715, Uí Néill hostility quickly reemerged (Smyth 1994, 93), before the Uí Dúnlainge seized back power and held it until the middle of the eleventh century (Clinton 2000, 277; Ó Cróinín 2005, 200). It is also at this point that we see Dún Ailinne and Óenach Carmain become important institutions in Uí Dúnlainge's provincial hegemony (see Grabowski 1990, 35; Gleeson and Ó Carragáin 2016). Interestingly, these locals were within the territories Uí Dúnlainge appear to have conquered in the seventh and eighth centuries, which might imply that the idea of a province of Leinster focused on these two sites was a creation of Uí Dúnlainge propaganda (Gleeson and Ó Carragáin 2016). This is supported by the fact that the Uí 
Cheinnselaig or Uí Máil kings of Leinster did not appear to have coveted Dún Ailinne and Óenach Carmain, but instead, fought for control of Dún Bolg and its environs.

In a more general sense, it would appear that northern Carlow and south-west Wicklow became the focus of Ui Cheinnselaig expansion around AD 500-650, their success being at the expense of the Uí Máil, much as Uí Dunláinge success in north-east Leinster was at Uí Máil expense too (Smyth 1994, 80). There is ample historical evidence to suggest an on-going feud between the Uí Máil and Uí Cheinnselaig (Smyth 1994, 80), with Dún Bolg perhaps the centrepiece of this dispute. By the middle of the seventh century, there are indications that the Uí Máil had begun to test the resolve of Uí Cheinnselaig power at Dún Bolg. A note in the Leinster king-list from the Book of Leinster, for example, records that Fiannamail mac Máeltuile, king of the Uí Máil and the Laigin, was slain by Fochsechán 'of his own people' in the battle of Aife, or Selgg, in Uí Máil territory (Smyth 1994, 93). As we shall see below, Aife can tentatively be linked with Kilranelagh, a hill located $1 \mathrm{~km}$ to the south of Dún Bolg, inferring that the latter was also within Uí Máil control.

By end of the seventh century, the Uí Máil had apparently completed an annexation of Dún Bolg, which latterly became their seat of power, a point later supported by the tenth century Fingal Rónáin saga focused on Dún Bolg and featuring heroic members of the Uí Máil in central roles (Greene 1955; Smyth 1982, 52). This in turn has led Gleeson (forthcoming) to suggest that Dún Bolg may have been as important as Carman and/or Dún Ailinne as a symbol of regional control for southern Leinster at this time. The fact that it was the target of a raid by Áed mac Ainmuire in 598 arguably intimates that status by at least AD 600, given considerable evidence for Áed's supraregional power (Charles-Edwards 2000, 441-69; Lacey 2006, 167-75).

Despite Uí Chennseláig being de facto rulers of southern Leinster (with a base emerging at Ferns) during the majority of the eighth-twelfth centuries, the Uí Máil seem to have held their position at Dún Bolg until at least the thirteenth century. The dynasty's name is preserved in the placename Glen of Imaal (Glinn Ua Máil; Figure 1) and in their association with the church of Donaghmore as 
Domnach Mór Ua Máil (Hogan 1910, 457). This was a strategic location protected to the north, east and south by an imposing mountain range which also allowed access to one of three major mountain passes connecting the east coast to the central midlands, providing access to goods traded from Britain (Smyth 1982, 51; 1994, 72). However, it is clear that the extent of Uí Máil hegemony was much more expansive. Abutting the territories of Cualu in south Co. Dublin controlled by Uí Chellaig Cualann and Uí Théig, Uí Máil territories further south were centred in the fertile western foothills of the Wicklow Mountains, the groups borders extending from the western extent of Kildare, north to Glendalough and east to the Glen of Imaal (MacShamhráin 1996; MacCotter 2008, 131). MacCotter's $(2008,177-8)$ reconstruction of the Omurthi cantred might suggest that Uí Máil territory contained the southernmost parts of modern Kildare, the eastern midlands of modern Wicklow and smaller portions of northeastern Carlow at a minimum. However, Price (1949b, 29-33) has convincingly demonstrated a more expansive territorial unit: he highlights a number of references in the 1310 Red Book of Ormond which set out the rental of land in Omayl (Uí Máil territory) which include the parish of Donaghmore and parts of Kilranelagh in the Cantred of Ofelmeth (MacCotter 2008, 177-8). Furthermore, in notes to the Martyrology of Óengus, it is recorded that one Cellach had his hermitage in Uí Máil at Disert Cellaig, south-east of Glendalough, somewhere in Glenmalure beyond the eastern limits Omurthi, while a confirmation grant to the Abbot of Glendalough in 1172-6 refers to 'half of Uí Máil', listing Cluaindartada (latterly known as Clonardinagory, now Tullygorey, Co. Kildare) within its bounds. This broadly supports the western extent of the cantred boundary being roughly equivalent to the limits to earlier Uí Máil territory, and that by the twelfth century, Ui Máil controlled a large and important tract of east-central Leinster (Price 1949b, 29-33). Any such territorial unit described, however, must be seen as a fluid construction, created through centuries of expansion and contraction associated with the development of the regional petty kingdoms. 


\section{Toponymy and the Dún Bolg Landscape}

The identification of Dún Bolg as the large hilltop fort known as Brusselstown Ring (Figure 2), located on the western edge of the Glen of Imaal, is often considered explicit (Price 1949a, 121). This argument is developed from the topographical description of the site in the Bórama Laigen (Stokes 1892, 55-95) which describes a major battle in the shadow of Dún Bolg, namely that intimated by AU598.2 (see above). According to this saga, the cause of this battle was the killing of Cummascach, son of Áed mac Ainmuire (Uí Néill), by Brandúb mac Eochu, the Uí Cheinnselaig king of Leinster. It begins as Cummascach, on a royal tour, went to Brandúb's house in Belach Conghlais (Baltinglass) and demanded the right to sleep with Brandúb's wife. It is notable here that the text specifically mentions Belach Conghlais, not only setting the conflict in this region, but also highlighting that the king of Leinster resided here. Much as the series of aforementioned annals, this hints that even at the end of the early medieval period, Dún Bolg was perceived as an important centre of power. In retaliation, Brandúb attempted to kill Cummascach by setting fire to the house, though the latter escaped and fled to nearby Móin Cummascaigh, near the faitche of Cill Rannaireach (Kilranelagh). Here the erenagh of Cill Rannaireach killed Cummascach in return for gaining exemption from tribute for the monastic centre. In retribution, and as an attempt to expand the territory of the Uí Néill, the next year, Áed mac Ainmuire invaded Leinster, continuing to Dún Bolg before setting up camp. After an unsuccessful attempt by Áedán of Glendalough (possibly of Kilranlagh, see Eyjólfsdóttir 2012, 49) to obtain a truce, Brandúb devises a plan and pretends to agree to provision the high-king's army and enter his camp hidden in baskets of food. After a prolonged battle, Áed mac Ainmuire was killed and buried at Kilranlagh, further implying that the battle was fought nearby (Price 1949a, 123). This was a decisive victory for Brandúb, who would be instrumental in halting the southern expansion of the Uí Néill, a feat further recognised in a poem in the Book of Leinster recording his 'seven blows against Brega'. In fact, it is likely that Brandúb succeeded in restoring territories lost to the Southern Uí Néill in earlier decades (Byrne 1973, 142), or perhaps even re- 
establishing Laginian overlordship of the south-central midlands. The Bórama Laigen was written in Uí Felmeda territory, a tribe who were descendants of Brandúb. This sept came to dominate all of Leinster in the eleventh and twelfth century, with Byrne $(1973,143-4)$ arguing that the saga was an attempt by their kings to glorify the memory of their ancestor. This is a problem with many of the sources of evidence for the fifth-early seventh centuries, including the both the Bórama Laigen and Fingal Rónáin, where the veracity of clearly retrospective accounts is coloured by contemporary political and ideological agendas.

The saga itself is nonetheless situated within the context of earlier annalistic narratives, which may or may not be contemporary and reliable. These authors attempted to situate this historically within the contemporary landscape by anchoring the narrative to important known localities. As such, the topographical lore may prove useful, even if in no way historically reliable. At the very least, it highlights sites that were of significance in the period of compilation. For example, the slain king Áed mac Ainmuire was reputedly buried at Kilranelagh, which Price $(1949 a, 121)$ suggests is an early tradition indicating his killing nearby. Likewise, another key fort in the narrative is Dún Buchat, mentioned as the secret shelter to which Brandúb sent his wife once the battle commenced. Price (1949a, 121) has argued that Dún Buchat was located near or at the faitche of Kilranelagh. A faitche was an area of open space outside a high-status dwelling, and hence, has here been linked with a levelled fort at the northeastern base of Kilranelagh Hill.

Brandúb's dún, mentioned at the beginning of the saga, is differentiated from that of Dún Bolg (which infers that Dún Bolg was a ceremonial centre rather than a place of residence). By way of parallel, we may note groups of royal forts associated with particular kingships: in a Leinster case, those described in Tímna Cathair Mar, or for Cashel and Tara, those listed in eleventh- or twelfthcentury tracts like Lebor na gCert or tracts on the taboos of kings (edited by Dillon 1951; 1962). This dún is described as being located on the Slaney River near Baltinglass. Price $(1949 a, 121)$ has convincingly argued that this description corresponds with a large univallate ringfort located a few 
hundred metres from the Slaney $4 \mathrm{~km}$ north of the Baltinglass. While the fort is levelled, the OS maps record a roughly oval monument with an interior measuring $54 \mathrm{~m}$ north-south by $45 \mathrm{~m}$ east-west, with an unusually wide external ditch up to $18 \mathrm{~m}$ wide. Remarkably, the fort is the largest example found within the parish of Rathbran, a land unit which presumably preserves the namesake of the famous sixth century Leinster king, Brandúb mac Eochu. Similarly, a concentration of multivallate ringforts surrounding the modern town of Donard (in the townlands of Blackmoor; Donard Lower; Kilbaylet Upper; Donard Demesne East) at the northwestern entrance to the Glen of Imaal, suggests the presence of a significant high-status early medieval settlement. Ó Carragáin (2015), for instance, has demonstrated that $86 \%$ of multivallate ringforts in the kingdom of Fir Maige are located on royal demesne, and Clinton $(2000,281)$ has linked this concentration around Donard with the royal residence(s) of the Uí Máil. As such, we may suggest that sites like Dún Bolg represent central places for these polities, rather than actual residences, much as landscapes like Tara, Dún Ailinne or Rathcroghan also seem to lack residential elements within their core complexes.

Another site, Bun Aife, is specifically mentioned and distinguished from Kilranelagh and Dún Buchat. According to the Bórama Laigen (Stokes 1892, 83), the Uí Néill king sends part of his army south towards Bun Aife, though Brandúb's men pass them when making their final attack. This infers Bun Aife was near the battle itself, and Price $(1949 a, 121)$ has convincingly argued that 'Aife' was the old name for Kilranelagh Hill. The twelfth century Agallamh na Senórach mentions a hill named Cnoc Aife, which is broadly located in southern Leinster (Price 1949a, 122-3), while in Fingal Rónáin, a character known as Máel-Fothartaig goes from the king of Leinster's house to hunt at 'Bae Aife'. To explain this location, the story adds that a group of stones that look like cows from afar (known as The Cows of Aife) are located on the side of a mountain called Aife. This prompted Price to note an outcrop of rock on the side of Kilranelagh that consists of a group of white stones which look like a herd of cows, suggesting that there are no other obvious topographical features like this in Wicklow and Carlow. Furthermore, the 1655 Down Survey in the Kilranelagh area records 'a heap of stones at White Cow Hill', which further supports the affiliation between Bun Aife and Kilranelagh Hill. Price 
$(1949 a, 122)$ also notes that in the list of the kings of Leinster, Fianamail mac Maeletuile is killed in the 'battle of Aife or Selgg' in AD 680, by Maine Mál, a progenitor of the Uí Máil. Fianamail is killed by his own people, so his death might perhaps be regarded as having occurred in Uí Máil territory. Smyth $(1994,95-6)$ further suggests that Aife and Selgg were the same place, which in turn infers that this is where the son's of Cellach Cualann, the last Uí Máil king to hold the kingship of Leinster, died, after he was defeated in the Liffey Plains around AD 709 by the Uí Néill king, Congal Cend Magair. Congal was the grandson of the Domnall who 'wasted' Leinster in AD 628 to avenge the slaying of his father and brothers at the battle of Dún Bolg. While the Uí Máil withdrew from the attack, preventing any major deaths, it created instability amongst the Laigin, leading to a major battle at Selgg where the Uí Cheinnselaig killed two of Cellach Cualann's sons.

A second major battle occurred at Dún Bolg around AD 870. The Fragmentary Annals of Ireland include an entry stating that Áed mac Níall, king of Ireland, marched into Leinster, plundering from Áth Cliath (Dublin) to Gabrán (Gowran Pass). Then Cerball mac Dùngal, king of Osraige, and Cennétig mac Gáerthíne, king of Loíches, came from the other side of Leinster, and they did 'as much burning and plundering and killing as they could until they reached Dún Bolg, and they camped there' (Frag. A. 387). Later the text notes how the two forces marched in 'orderly battalions', inferring a large fighting force that would suggest Dún Bolg was envisaged in the period of compilation as a fortress capable of accommodating a large army. The Leinstermen rallied behind their king, Muiredach mac Brán, and attacked the enemy at Dún Bolg. A description of the battle records some of the army 'in the clefts of the rocks', which would correspond with the rocky outcrop over much of the southeastern part of Spinans Hill/Brusselstown Ring.

Another prominent saga, Fingal Rónáin, firmly roots the seat of seventh century Uí Máil power in west Wicklow, and more specifically, in the area around Kilranelagh and the neighbouring hills (Smyth 1994, 103). The fortress of Rónain, who is identified as the king of Leinster, is described as 
being located near 'The Cows of Aife', which would accord well with the situation of Dún Bolg near Bun Aife.

As Smyth $(1994,105)$, states, 'a notable feature of early Irish political history is the regular recurrence of battles at key locations, usually at border-crossings, in a strategic pass, or in the vicinity of royal strongholds (Smyth 1994, 105-6). We see this clearly with Dún Bolg, where there is a link between this fortress and both Uí Cheinnselaig and Uí Máil kings, who both purposefully usurped the fort to use as their royal seat. Regardless of which dynasty held the fort, it continually drew the brunt of Uí Néill aggression, particularly during the sixth-seventh centuries before the regional ascendancy of Uí Dúnlainge in the eighth century.

Indeed, the focus on Dún Bolg as an important place of regional and possibly provincial kingship in the sixth-seventh centuries may have been borne from an earlier tradition. Smyth $(1994,48)$ notes that the Uí Lopéni, a branch of the Dál Messin Corb, were located around Kilranelagh, suggesting that this tribe controlled the western foothills of the Wicklow Mountains towards eastern Kildare and the Glen of Imaal, prior to the Uí Felmeda attaining these lands (probably in the sixth century). Though there are problems with distinguishing between the collateral lineages of Dál Messin Corb, who are found throughout Leinster, the southern midlands and north Munster (see MacShamhráin 1996), we might tentatively suggest that Dún Bolg could have been a regional centre of power for Dál Messin Corb prior to Uí Chennseláig and Uí Máil ascendance. Bhreathnach $(2000,312)$ notes that kings were strongly aware of the importance of these ceremonial sites; their importance in the creation and maintenance of power and authority was crucial during a period when nascent kingdoms were jostling for control, and as such, the control over known, established centres may have been a major source of conflict. It is possible that Dún Bolg's significance originates in just such a context. 


\section{The Early Medieval Archaeology of the Baltinglass Area}

Taking the literary, genealogical and annalistic evidence into account, there are significant indications that Dún Bolg was linked with other important sites in the Baltinglass area and associated with regional kingship. This implies that there was a sustained royal focus here, perhaps even the ceremonial centre of a wider regional kingship. However, there has been no comprehensive attempt to merge the archaeology of these sites into this historical framework, and the remainder of this paper seeks to address this issue.

\section{Dún Bolg}

It is no coincidence that this early medieval power centre is located within the densest concentration of prehistoric hilltop fortifications in Ireland (Figure 1). There are nine 'hillforts' in the Baltinglass complex, a unique concentration in both an Irish and British context (O'Driscoll 2016, 111). Most of these are large, well preserved enclosures still visible today and would have been revered in the early medieval period as major centres of ancient dynasties. This palimpsest of massive enclosures no doubt influenced the development of the early medieval landscape and its perception.

Dún Bolg (Spinans Hill 2), as well as two other large hilltop forts (Spinans Hill 1 and Brusselstown Ring), is located on Spinans Hill, located at the eastern side of this complex (Figure 3 and 4). All three lie on an north-east/south-west running hill with two summits. The northern summit rises to a maximum height of $406 \mathrm{~m}$ OD and is surrounded by Spinans Hill 1 . The southern summit at $386 \mathrm{~m}$ OD is surrounded by Brusselstown Ring, with Spinans Hill 2 enclosing both. Unfortunately, the nearsurface igneous bedrock prevented geophysical survey, though topographical analysis has produced excellent results. The latter was undertaken using drone derived photogrammetry and GPS survey.

\section{Brusselstown Ring}


Brusselstown Ring is a large bivallate hillfort with widely spaced stone ramparts enclosing a total area of 41.19ha, located on the southeastern ridge of Spinans Hill (Figure 2 and 4). The inner enclosure closely follows the $370 \mathrm{~m}$ contour and comprises a stone rampart of varying width (maximum $11.7 \mathrm{~m}$, minimum $5.3 \mathrm{~m}$ ) surrounding a natural oval terrace $4.63 \mathrm{ha}$ in size. Four entrances have been identified at the north, south, east and west (O'Driscoll 2016, 155). The outer rampart is located 124-305m outside the inner enclosure, but unlike the latter, does not follow the contours, varying from $366-298 \mathrm{~m}$ OD. It comprises a less substantial stone rampart best preserved to the north, where it averages $10.2 \mathrm{~m}$ in width. There are obvious entrances in the outer bank, although overgrowth may obscure such features.

A combination of GPS and photogrammetery survey has recorded up to 489 possible hut platforms scattered within the southern and eastern slopes of the fort, with an additional settlement area comprising enclosures, hut sites and field walls immediately to the north-west (Condit 1992, 16-20). The density and layout of these platforms compares with other Bronze Age upland nucleated settlements such as Mullaghfarna and Turlough Hill (Bergh 2015), though on a much larger scale.

\section{Spinans Hill 1}

On the northern summit of Spinans Hill, Spinans Hill 1 comprises an irregularly shaped area enclosed by a stone rampart over an area of 11.11ha (Figure 4). No habitation evidence has been identified within the interior, though seven cairns probably represent a passage tomb cemetery (Condit 1992, $20 ; 1998,20)$. Targeted excavation of the northern side of the rampart returned two identical dates of 3697-3527 BC from the lower rampart core and pre-rampart surface, suggesting a probable Early Neolithic date (O'Brien and O'Driscoll 2017, 249).

\section{Spinans Hill 2}


Surrounding Spinans Hill 1 and Brusselstown Ring is an extensive earthwork 131ha in size known as Spinans Hill 2 (Figure 4). Over the course of its perimeter, the enclosure varies from 295-368m OD. Photogrammetry and field survey revealed two distinct sections; the first comprising a bank/ditch/counterscarp arrangement, the second consisting of a stone rampart that also acts as the second enclosing element of Brusselstown Ring. This particular arrangement may indicate that Brusselstown Ring was constructed before Spinans Hill 2, though their absolute dating is still in question. It is possible (and even likely considering the dating of other large hilltop enclosures) that both date to the Middle/Late Bronze Age, with re-use occurring in the Late Iron Age/early medieval period.

\section{Identifying Dún Bolg}

Raftery $(1994,63)$ has drawn comparisons between Spinans Hill 2 and the large series of cross-dykes known as the Dorsey in Co. Armagh. While the scale of the works is comparable, these dykes likely served as defensive earthworks protecting multiple fording points in rivers (Condit and Buckley 1989). Moreover, Spinans Hill 2 encloses a hilltop and is not a gateway in the fashion of the Dorsey or the Dun of Drumsna (Condit 1998, 23). More recently, Flood $(2009,83)$ has proposed Knocknarea Mountain in Co. Sligo as a possible parallel. Bergh $(2000,14)$ discovered a system of discontinuous banks on the eastern summit of the mountain which effectively blocked the peak from the lower shoulder. These features have been tentatively dated to the Neolithic and their slight nature makes them a poor comparison. More appropriate similarities can be found in Britain and the Continent. Ham Hill in Somerset, England, for example, surrounds a prominent limestone plateau and consists of two ramparts enclosing an area of approximately 84ha (Smith 1990). Similarly, Bindon Hill in Dorset, England, approximately 114ha in size, surrounds a chalk ridge overlooking the English Channel. It comprises a large rampart and ditch surrounding another smaller hillfort (Wheeler 1953). The site has variously been interpreted as an invasion base, assembly place or trading centre rather than a densely populated defensive settlement (Hogg 1975, 36). The latter was dismissed due to the 
extensive perimeter, which it is argued could not have been adequately defended. Raftery $(1994,63)$ supports this interpretation and has questioned the defensive function of Spinans Hill 2. Regardless, whatever the function of these massive earthworks, it is clear that their construction represent a huge and concentrated effort by a significant number of people, and demarcating a place of exceptional importance (Raftery 1994, 63).

Path-Distance Catchment models for the enclosures on Spinans Hill suggest that, unlike the other hilltop forts in the Baltinglass area, there is easily accessible land to the north and north-east, particularly the Glen of Imaal (O'Brien and O'Driscoll 2017, 374-5). Viewshed analysis reveals extensive views of this area from all of the hillforts on Spinans Hill but indicates visibility of the lowland to the south was also important (O'Brien and O'Driscoll 2017, 375). The significance of the Glen of Imaal is apparent through the notable concentration of visibility towards the east and northeast. There are excellent views to the lowland in the south, although this is partially obscured by Kilranelagh.

Cumulative viewshed, which consists of the repetitive process of applying viewshed analysis on the same raster terrain multiple times with different point data (O'Driscoll 2017), implies Spinans Hill is a significant topographical feature in this landscape (Figure 6). Populating the Glen of Imaal (an area of just over $41 \mathrm{~km}^{2}$ ) with 2000 random viewer points produces a gradient map of prominent locations. The results show that parts of Spinans Hill 2 are visible to 1832 of the 2000 viewer points, with the majority of the hill being visible from 1703 positions. Apart from the nearby Keadean Mountain, Spinans Hill is the most prominent location from the Glen of Imaal, despite the valley being defined by a contiguous series of hills and mountains. Significantly, Brusselstown Ring shows a much more restricted field of visibility.

Considering the relative chronology of the forts on Spinans Hill, the impressive size of Spinans Hill 2 and its prominence in the Glen of Imaal, we argue that this is the best candidate for Dún Bolg, though absolute dating for early medieval activity or (re-)construction is needed to clarify this. Other 
Late Iron Age/early medieval royal centres and assemblies often seem to have focused on large hilltop enclosures that occupy prominent positions within their respective landscapes (Wailes 1982, 51; Newman 1998, 135; Gleeson 2014, 177; Gleeson 2017b, 12). At least some of these seem to have been re-used hillforts (e.g. Clogher, Grianán of Aileach, Ballymount Great or the Hill of Lloyd). In the early medieval period, hillforts like those of the Baltinglass group, may have been seen as the physical manifestation of successful ancient dynasties who inscribed the landscape with massive and enduring fortifications. Early medieval elites may have attempted to re-imagine these forts as the physical monuments of known ancestors in an attempt to affirm their place and power in contemporary society. In this regard, the enormous scale of Dún Bolg would certainly have attracted the attention of these elites.

While the identification of Dún Bolg with Spinan's Hill 2 must remain tentative, it is nonetheless apparent that the site was identifiable with one of the enclosures on this hilltop, if not the complex they formed together. The scale, visibility and overall dominating character of these sites suggests that this was a powerful place, one imbued with history and likely associated with ancestor figures in a heavily mythologised landscape, of which we see only glimpses in tracts like Fingal Rónáin or the Bórama Laigen.

\section{Kilranelagh}

Kilranelagh also features prominently in the historical literature, though these sources suggest that the hill had a more protracted and complicated history than the recorded archaeology supports (Figure 1). Here again, recent archaeological survey has revealed newly identified features.

The western slopes of Kilranelagh are defined by a distinct flat terrace upon which a large $120 \mathrm{~m}$ diameter enclosure surrounds Kilranelagh church, graveyard, St. Bridget's Well and two high-crosses. The church is further delimited by a D-shaped earthen bank. Considering the toponymic element 
${ }^{*}$ cill, the archaeological remains, and references in early sources, this is almost certainly an early medieval ecclesiastical site; by the fourteenth century, it was being referred to as an 'old romantic burial ground' (O'Toole 1890, 178). It is more than likely, therefore, the Cill Rannaireach mentioned in Bórama Laigen.

On the summit of Kilranelagh, O'Driscoll $(2016,164-6)$ has identified a large enclosure some 5.33 ha in size (Figure 7). The enclosing elements are visible on the surface to the west and south-west, where they comprise a stone rampart approximately $14 \mathrm{~m}$ wide and up to $0.6 \mathrm{~m}$ high. There is evidence for external facing and a change in vegetation may indicate the presence of an outer ditch. There are no obvious internal features. The south-western section of the perimeter abuts a large cairn, with two other cairns recorded on the western slopes outside the fort. A stone circle and barrow have been identified on the eastern slopes, as well as a badly weathered Ogham stone which forms part of a cluster of such monuments focused on the Baltinglass area. These alone are indicative of high-status forth-seventh century occupation. Outside the main cluster of Ogham stones in the Cork/Kerry/Waterford region, notable concentrations occur around important Iron Age/early medieval centres such as Freestone Hill, Co. Kilkenny, Rathcroghan, Co. Roscommon, or the Hill of Tara and Raffin Fort in Co. Meath. That this cluster represents a further group around Dún Bolg is highly significant.

Considering the already outlined connections between the name Aife and Kilranelagh, it is possible that the newly discovered enclosure on Kilranelagh is a large prehistoric hilltop fort that was reimagined as Bun Aife during the early medieval period.

At the northern base of Kilranelagh, Price recorded a large enclosure (Corlett and Weaver 2002, 540). He describes the remains as an outer ditch approximately $10 \mathrm{~m}$ wide with an internal bank and inner ditch. He also recorded a small cairn and surmises that this may be the location where a 'Late Bronze Age urn' was discovered. In this area, aerial survey has confirmed the presence of an enclosure which survives as an oval vegetation mark approximately $172 \mathrm{~m}$ in diameter occupying an 
area of 2.37ha. The enclosure and surroundings are overgrown, making further identification of features difficult. Price $(1949 a, 121)$ has argued that this enclosure is the 'Dún Buchat' mentioned in the Bórama Laigen.

\section{The Dún Bolg Environs}

While we have a number of candidates for the locations and forts mentioned in the historical sources, including Dún Bolg, Cill Rannaireach, Brandúb's dún , Bun Aife and Dún Buchat, as well as a potential royal settlement for the Uí Máil near Donard, there are other monuments not referenced in the literature that hint at the importance of the area in this period. Of particular significance is the identification of the placename Donaghmore, which survives as the name of a large parish immediately north of Spinans Hill (Figure 1). From Domnach Mór ('Great Church'), the first element domnach signifies an early conversion-period church. Derived from the Latin dominicum, it is widely agreed that this was no longer an active toponym by around AD 500 (Flanagan 1984). Furthermore, domnach placenames normally signify that the ecclesiastical site in question was the principal church of a defined geographical area (i.e. a plain) or a discreet kindred or dynasty, while a significant pattern has been identified in the location of these churches, often to be found in proximity, at the edge of early royal estates and assembly places (Gleeson 2015, 43; 2017a, 79). Gleeson $(2017 a, 79)$ has convincingly argued that assembly places and practices were a focus of missionary activity, stating that at least 39 of some 118 assembly landscapes known in Ireland are specifically associated with these domnach churches. In this instance, the church at Donaghmore is strategically located at the entrance to the Glen of Imaal, visible to, and just beyond the northern edge of Spinans Hill 2, further supporting the interpretation of this as the royal site, Dún Bolg. The importance of this Donaghmore is further emphasised by the fact that only three such sites have 
been identified in Carlow, Wicklow and Kildare. Located within this parish is a post-medieval church erected in AD 1711.

Some scholars (Smyth 1982, 27-8; Gleeson 2015, 43-5) have highlighted that royal centres often occur in close proximity to other important places such as early churches, royal inauguration places, assembly complexes and/or ancient burial cemeteries. While the former has already been highlighted, we can also identify other elements of this royal 'package'.

Approximately $1.5 \mathrm{~km}$ to the west of Donaghmore church, in Castleruddery townland, a large subcircular mound is located close to the Slaney River. and is highly visible from Spinans Hill (Figure 8). The mound measures $50.37 \mathrm{~m}$ east-west by $49.2 \mathrm{~m}$ north-south, with a maximum height of $2.07 \mathrm{~m}$, and sits in a natural hollow. There is no evidence for enclosing elements on the summit or at the base of the mound, though a $12 \mathrm{~m}$ wide berm might suggest that material scrapped from immediately surrounding the mound was used in its construction. The summit is partly dished and slopes to the south, which broadly corresponds with the surrounding topography. The edge of the mound is steep and there is no obvious ramp or entrance. There is a small oval hollow to the southwest of the mound, though this is probably modern.

The classification and purpose of this monument is not clear. It could be interpreted as a raised rath, a burial mound (ferta) or an inauguration mound. Raised raths, or platforms raths, are a sub-group of the 'ringfort' monument commonly found throughout Ireland. Whenever recorded, they seem to constitute between $15-20 \%$ of this classification and may represent a more narrowly defined elite, albeit from around AD 750-950 (Kerr 2007; Stout 2017, 162). This would place its construction after the annexation of the region by the Uí Máil. Considering we have already proposed that the concentration of multivallate forts near Donard was the royal settlement of this tribe, it is more likely that this mound is not a royal residence. The absence of any form of enclosing element, a common characteristic of a raised rath (Lynn and McDowell 2011, 28), infers this is unlikely to be a secular monument. The mound shares a similar landscape position to that of Magh Adhair, Co. Clare, 
the inauguration site of the Dál Cais, which is similarly located in a hollow prone to flooding. The mound itself may have been built in prehistory, with many of the nearby monuments attesting to Bronze Age or Neolithic origins. For example, approximately $450 \mathrm{~m}$ to the east of the mound, a rare embanked stone circle may date to the Late Neolithic (Cleary and O'Driscoll 2014, 32) and is surrounded by a series of cairns, while a cluster of five large barrows, one standing stone and a Linkardstown burial (Ryan 1973) are located $1.3 \mathrm{~km}$ to the south. O'Driscoll $(2016,217)$ has recorded up to 105 barrows within the Baltinglass area, representing a significant number of burial monuments that may have been revered as ancient burial places during the medieval period, if not actually used during that period. Certainly, the passage tomb cemetery on the northern summit of Spinans Hill may have further emphasised the hill as an appropriate location for ceremony.

Bradley $(2002,47)$ argues that the past in contemporary society was particularly important during periods when new regions were settled and new relationships formed between people and the land. Particularly in this early period of conversion and geo-political change, such control of 'media' believed to be closely related to ancestry played a significant role in the social and cosmological order of societies; these were crucial to legitimate rule (Kristiansen and Larsson 2005, 45; Semple 2013 1-6; 9; Waddell et al. 2009, 205; O’Driscoll 2016, 330).

Within this sort of context, the mound at Castleruddery could have been re-used in the early medieval period for ceremonial purposes. Such monuments, along with other ancient burial sites, were important in the inauguration rituals of medieval kingdoms (FitzPatrick 2004; Gleeson 2012, 1; 2014, 182-183). Indeed, the mound, barrow cemetery, early church site, Spinans Hill (Dún Bolg) and much of the Glen of Imaal itself are within Donaghmore parish, which comprises the largest parish of the barony of Talbotstown Upper at $95.18 \mathrm{~km}^{2}$. Considering its size, there is a distinctly small number of known church sites within it (four), while large concentrations of churches sit just outside the parish on all sides (Figure 9). This pattern is also mirrored in the distribution of possible early medieval 'cemetery settlements' (see below). Might this parish represent the royal lands 
surrounding Dún Bolg, with royal power limiting the presence of the church within this landscape? The possibility that Domnach Mór Ua Máil was an early, conversion-period royal foundation would support that assertion.

\section{Rathmoon and Other Cemetery Settlements}

Further evidence for early medieval activity and possibly assembly functions can be found in cemetery settlement-like complexes within this landscape. Rathmoon is recorded as a large, levelled enclosure located at the flat southeastern foot of Hughstown Hill, near a substantial Neolithic burial mound destroyed in the 1960s (Figure 1). The site is depicted in the OS maps as a univallate enclosure, though aerial and satellite imagery reveal a more complex system of somewhat concentric enclosing elements. This is reflected in the magnetic gradiometry survey, which show a sub-oval enclosure, comprising a series of up to four widely-spaced enclosing elements measuring $160 \mathrm{~m}$ (east-west) by $120 \mathrm{~m}$ (north-south), increasing the total size of the monument to $1.71 \mathrm{ha}$ (Figure 10 and 11).

Cemetery settlements are generally characterised by a series of large sub-circular or oval enclosures, with the central enclosure defining burials outside of which other activities such as craft-working, crop-processing and ceremonial feasting took place (O’Sullivan et al. 2008, 179; Ó Carragáin 2009, 135-137; 2010, 217). O'Sullivan et al. $(2008,179)$ have noted that these sites often lack a church, as well as having limited evidence for domestic structures. Gleeson $(2015,43)$ further argues that these sites were local community assembly and burial locations for specific kin groups within a túath. The chronology of these sites may vary, with Johnstown 1 in Co. Meath dating to the forth-seventh century (McCormick and Murray 2007, 243-5) and Carrowkeel, Co. Dublin dating to the eightheleventh century (O'Sullivan 2007). O'Sullivan et al. $(2008,177)$ argue that the dating evidence does not indicate origins predating the Late Iron Age/early medieval period, though they do note that 
some sites may be associated with prehistoric funerary monuments. Likewise, it appears that there is very little evidence for these sites being founded after the eighth century, even if a few do remain in use until the eleventh century and beyond. Importantly, Gleeson and Ó Carragáin $(2016,104)$ and Gleeson $(2017 b, 75)$ suggest that the majority tend to cluster together near parish boundaries and within known assembly landscapes. Rathmoon fits this description, being located near the major royal fortification of Dún Bolg, at the western edge of the parish boundary of Baltinglass abutting the county boundary dividing Wicklow, Kildare and Carlow.

One of the most powerful septs of the Uí Cheinnselaig were the Uí Felmeda, who settled in the lands about Dún Bolg from the sixth century. During this period, the Uí Felmeda provided some of Uí Cheinnselaig's most famous kings, including Brandúb, his father, Eochu, his grandfather, Muiredach, and his great grandfather, Óengus. Regardless of how accurate the images painted by later synthetic historians may be, this nevertheless highlights the significance of Uí Felmeda, and again supports the perceived importance of the Baltinglass region at this time. It is in this context we might suggest that the cemetery settlement of Rathmoon acted as the local assembly for some of the kin groups of this sept.

The size, layout and morphology of Rathmoon is typical of other cemetery settlements. Rathmoon is particularly comparable in size to Knowth, Site M, Co. Meath (Stout and Stout 2008), though there are far smaller examples, such as Westereave, Co. Dublin, which measures approximately $25 \mathrm{~m}$ in diameter; the average size being between 50-70m (O'Sullivan et al. 2008, 178).

The enclosing elements at Rathmoon are spaced between 15-22m apart and generally follow the contours of the hill. The two outer enclosures do not form complete circuits and are appended to the inner enclosures, creating an uneven distribution. The geophysical results suggest that these anomalies are cut features, most likely ditches. The outer example (G2) is less prominent, though this may be a consequence of water-logging. The enclosing elements $\mathbf{G 4}$ and $\mathbf{G 8}$ consist of significantly stronger readings indicating the fill was not deposited by natural erosion processes. It is 
tempting to speculate that the fill is associated with ceremonial feasting, with the ditches being used as middens for food- and metal-working waste, as demonstrated in excavated examples. As noted by O'Sullivan et al. $(2008,180)$, where soil conditions are favourable, these sites have tended to produce large quantities of animal bone, and this has explicitly been connected with feasting activities as a part of seasonal assemblies by Gleeson $(2015,40)$.

Both ditches measure around $8 \mathrm{~m}$ in width. An internal band of negative magnetic readings (G5) on the southern section of $\mathbf{G 4}$, measuring up to $9 \mathrm{~m}$ wide, probably represents an internal bank. A series of radial banks linking the outer two enclosures (G1a-G10) were probably created for cultivation and animal grazing, though without excavation, we cannot be certain whether these are contemporary with the use of the enclosures. At Knowth Site M, for example, cultivation furrows both truncate, and were truncated by, early medieval burials (Stout and Stout 2008), indicating that the site was incorporated into yearly agricultural practices while actively being used as a burial foci. The anomalies that define the two inner enclosures (G8 and $\mathbf{G 1 0}$ ) are notably different from the latter, comprising a series of much higher magnetic responses $1.5-4 \mathrm{~m}$ in width. The inner enclosure is sub-divided by an annular band of magnetism (G12). While the strength of these readings could represent in-situ burning, the enclosures are apparent in the aerial and satellite imagery as vegetation marks that likely represent larger cut features. As such, they probably represent ditches that have been filled with highly magnetic material. The difference in the width of the inner and outer enclosures may infer they were constructed at different periods.

It is typical for cemetery settlements to expand through time, with additional enclosing elements being appended to one of the core enclosures, often as a facet of the burial space being expanded (O'Sullivan et al. 2008, 178). At Corbally, for example, two enclosures were added to a ring-ditch that was subsequently cut by burials (Coyne 2010). It is probable that, at its peak, all four of the enclosing elements at Rathmoon were in use at the same time. This is inferred by a series of corresponding entrances on the eastern side (G3, G6a, G9a and G11a). It is notable that this is the only side of the 
enclosure where all four enclosing elements overlap. This may have been a deliberate attempt to monumentalise the entrance area. There are two other corresponding entrance breaks at the south (G6b and G9b).

Five faint circular features were identified within the monument (G14-G18). These range 6-8m in diameter and could represent hut structures or ring-ditches. Domestic structures are uncommon at cemetery settlements, though industrial activity in the form of craft- and iron-working often took place. It is possible that these structures are associated with such activities, although excavation is needed to clarify their significance.

Within the northern part of the inner enclosure and immediately outside its entrance, there is a concentration of pit-like features, as well as a strong number of magnetic responses (G13). These could be interpreted as burial features, though some connection with industrial or craft activities cannot dismissed. This corresponds with Ó Carragáin's $(2010,217)$ observation that the burial precincts at these sites were usually well-defined and surrounded by much larger enclosing elements. The cemeteries themselves can vary in size, with Mount Offaly in Co. Dublin producing 1553 burials in total (Conway 2000, 36).

While it seems reasonable to interpret Rathmoon as a cemetery settlement, the site is one of a cluster of large multivallate sub-oval enclosures located in lowlying positions in the Baltinglass landscape. Just over $3 \mathrm{~km}$ to the west of Rathmoon, sitting at the eastern base of Corballis Hill and at the edge of a parish and townland boundary, a large oval enclosure 1.05ha in size is marked on the OS maps. On the ground, this enclosure is apparent as a more complex series of two closely set banks with external ditches measuring up to $33 \mathrm{~m}$ wide, with an additional annex to the south. Considering the additional features identified at Rathmoon through geophysical survey, it is possible that future investigations here could reveal an even more complex series of enclosures defining a comparable complex. 
Approximately $11 \mathrm{~km}$ to the west of Baltinglass another four sites may comprise previously unrecognised cemetery settlements; Grangerosnolvan Upper, Mullaghreelan, Kilkea Upper and Rathsillagh Upper (all Co. Kildare; Figure 1). While these may be beyond the limits of the Dún Bolg landscape, they suggest that this monument form may be more commonly found than current distribution maps suggest (Stout and Stout 2008 suggest a north Leinster currency). Indeed, Mullaghreelan is the likely caput of Uí Gabla Roírend (O'Brien 1962, 74, 339; MacShamhráin 1996, 72), presenting the possibility that the site in question is this possible cemetery settlement complex. Further to the west, excavations at Ardreigh (Opie 2004), in Co. Kildare, revealed in excess of 1700 undated burials. While many of these probably relate to the parish church and are later medieval in date, a number of large curving ditches were identified below some burials, possibly indicating that the site originated as a cemetery settlement. More comparable with Rathmoon, however, is Grangerosnolvan Upper. Aerial photography clearly shows the cropmarks of three enclosing elements; an internal sub-oval enclosure $0.25 \mathrm{ha}$ in area located at the northern edge of the interior of two larger enclosures with a total footprint of $0.94 \mathrm{ha}$. A potential kidney-shaped annex may be attached to the eastern edge of this monument. Indications of corresponding entrances at the south/south-east are apparent, as to is evidence for the widening and elaboration of the enclosing elements around the entrance. There are also indications of at least two small ring-ditches near this entrance that parallels Corbally, Co. Kildare (Coyne 2010). While these sites are not as conclusive due to an absence of excavation or geophysical survey, they're size, morphology and topographical locations suggest that they could be tentatively identified as cemetery settlements. While this is important for adding to a growing corpus sites found outside the areas within which they were originally identified, it also presents the possibility that such complexes might be recognisable as field monuments in and of themselves.

The distribution of these sites parallel that of churches in the area, being located beyond the edge of the parish of Donaghmore. Gleeson $(2017,77)$ has noted a similar pattern at Óenach Carmain, Óenach Roigne and Óenach Maoinmaighe, the respective assemblies of the Laigin, Osraige and Uí 
Fhiachrach. In all cases a variety of early medieval burial complexes were located around the peripheries of these landscapes. In the case of Carmain, complexes in the townlands of Corbally, Greenhills, Mullacash and Coughlanstown were placed at the edges of Carnalway parish, which MacCotter (2016) has identified as a royal estate. It would seem that this pattern is a more widespread practice, identifiable across the island, and perhaps further afield (Gleeson 2017, 78-9), which is reinforced by the identification of a possible cemetery settlement in Mullaghreelan as the caput of Uí Gabla Roirend. While these pieces of evidence support the possibility that the parish boundary of Donaghmore could represent the approximate limits of a royal estate centred on Dún Bolg, this cannot be conclusively proven without more holistic interdisciplinary analysis.

\section{Conclusions}

The study of early medieval Irish royal landscapes has progressed significantly over the past few decades, developing from the focused investigations of the well-known 'ancient' capitals at Navan Fort, Dún Ailinne, Rathcrogahn and Tara, to more nuanced studies of regional kingdoms and dynasties that are more representative of governance and rulership as a whole (e.g. FitzPatrick 2004; Gleeson 2014). Broader advances can be made with regard to the commonalities shared between such sites, and it does appear to be common to find a caput with nearby inauguration and assembly locale (Warner 1988, 53; Gleeson 2015, 33). Of course, we cannot be too rigid in applying such frameworks. Wailes (1982) or Warner's (1988) 'check-list' of archaeological criteria indicative of such royal landscapes, therefore, seems mute in comparison to Newman's $(1998,129)$ assessment, which argues that corroborating information, such as the location, scale and morphology of complexes with recognition of their 'special significance' in documentary sources, may prove to be a more reliable indicator. A considerable problem in this regard is the documentary evidence, which is not always present or is perhaps too subjective to be reliable. What can be certain is that there is a pressing need for more integrated, landscape-scale and interdisciplinary programmes of analysis. 
Such analysis in the case of Brusselstown Ring and Spinan's Hill, has identified a major royal centre of Dún Bolg, and helped to compose the landscape of a significant but neglected early medieval power centre. This landscape was a major central place in Leinster connected with Uí Cheinnselaig and latterly Uí Máil. At least in this case there seems sufficient corroborating documentary and archaeological evidence to identify Dún Bolg with the forts on Spinans Hill, and probably more specifically Spinans Hill 2, the massive fort a few kilometres east of Baltinglass town. From the documentary evidence, for instance, we can see that Dún Bolg is near Belach Conghlais (Baltinglass) and Cill Rannaireach (Kilranelagh), while also in close proximity to other subsidiary forts, namely Dún Buchat, Bun Aife and Brandúb's dún. The site must have been large and imposing, of significant enough scale to be able to accommodate a substantial army while also having rock outcrop within it. Furthermore, we can see that the royal landscape of Dún Bolg appears to have been demarcated by contemporary ritual or ecclesiastical sites, including an early domnach church, located in close proximity to a series of highly visible prehistoric monuments, ancient burial sites, ogham stones and early medieval cemeteries. As argued above, Spinans Hill 2 fulfils all of the criteria to be identified as the most likely candidate for the royal fortress known as Dún Bolg, though it is also possible that Brusselstown Ring, or indeed the complex of forts on Spinans Hill as a whole, performed such a role. Spinans Hill probably acted as the core focus for an assembly landscape of Uí Cheinnselaig and Uí Máil kings, as well as other sixth-seventh century kings who wished to rule south-central Leinster. The scale and extent of the archaeological evidence agrees with the intimations of documentary sources. While the Bóraime saga may not reliably indicate the significance of Dún Bolg in the fifthseventh century, it certainly attests to its long-standing importance, continuing, it would seem, the regional significance that is implied in the annals of the sixth and early seventh century, at least to the end of the early medieval period. As such, the identification of Dún Bolg, and the elucidation of its wider archaeological landscape, is significant for presenting another major centre of power and supra-regional kingship in early medieval Ireland, comparable perhaps in the fifth-seventh centuries to the so-called provincial centres. Adding thereby new data to that small but significant corpus of 
sites, further analysis will hopefully clarify the character and chronology of many of the sites examined here.

\section{Bibliography}

Al: Annals of Inshfallen, CELT database: https://celt.ucc.ie//published/T100004/index.html [last accessed 07th April 2020].

AU: Annals of Ulster, CELT database: https://celt.ucc.ie//published/T100001A/index.html [last accessed 22nd November 2019].Bergh, S. 2000 Transforming Knocknarea. Archaeology Ireland 14 (2), 14-18.

Bergh, S. 2015 Where worlds meet. Two Irish Prehistroci mountain-top 'villages'. In Moscatelli, U. and Stagno, A. (eds) Archaeology of Europe's Mountain Areas. Fermo, University of Macerata, 21-44. 
Bhreathnach, E. 2000 Kings, the kingship of Leinster and the regal poems of laidshenchas Laigen: a reflection on dynastic politics in Leinster, 650-1150. In Smyth, A. (ed.) Seanchas: Studies in Early and Medieval Irish Archaeology, History and Literature in Honour of Francis J. Byrne, 299-312. Dublin. Four Courts Press.

Bradley, R. 2002 The Past in Prehistoric Societies. London. Routledge.

Byrne, Francis John. 1973 Irish Kings and High-Kings. London. Batsford.

Charles-Edwards, T. M. 2000 Early Christian Ireland. Cambridge. Cambridge University Press.

Charles-Edwards, T. M. 2013 Wales and the Britons, 350-1064. Cambridge. Cambridge University Press.

Cleary, R. and O'Driscoll, J. 2014 Archaeological remains and geophysical surveys at Lough Gur and Grange stone circle. In Dalton, C. and O'Carroll, E. (eds.) Irish Quarternary Association Field Guide No. 32. 31-44. Dublin. Irish Quaternary Association.

Clinton, M. 2000 Settlement patterns in the early historic kingdom of Leinster (seventh to mid twelfth century). In Smyth, A. (ed.) Seanchas: Studies in Early and Medieval Irish Archaeology, History and Literature in Honour of Francis J. Byrne, 275-98. Dublin. Four Courts Press.

Condit, T. 1992 Ireland's hillfort capital: Baltinglass, Co. Wicklow. Archaeology Ireland 6 (3), 16-20.

Condit, T. 1998 Observations of the Baltinglass hillfort complex. In Corlett, C. and O'Sullivan, A. (eds.), Wicklow Archaeology and History 1, 9-25.

Condit, T. and Buckley, V. 1998 The Doon of Drumsna: an Iron Age frontier fortification in Connacht. Archaeology Ireland Heritage Guide (1). Dublin. Wordwell. 
Conway, M. 2000 Mount Offaly, Cabinteely: early medieval and enclosed cemetery. In Bennett, I. (ed.) Excavations 1998: Summary Accounts of Archaeological Excavations in Ireland, 36-7.Dublin. Wordwell.

Corlett, C and Weaver, M. 2002 The Liam Price Notebooks: the Placenames, Antiquities and Topography of County Wicklow, Vol. 2. Dublin. Department of Arts, Heritage and the Gaeltacht.

Coyne, F. 2010 Corbally, Co. Kildare: the results of 2003-4 excavations of a secular cemetery. In C. Corlett and M. Potterton 2010, Death and burial in early medieval Ireland, 77-90. Bray. Wordwell.

Dillon, M. 1951 'The taboos of the kings of Ireland', Proceedings of the Royal Irish Academy, $\mathbf{5 4}$ (C), $1-36$.

Dillon, M. 1962 Lebor na gCert. Dublin. Irish Texts Society.

Eyjólfsdóttir, E. 2012 The Bóruma: The Poetry and the Hagiography in the Book of Leinster. Unpublished PhD Thesis, University of Glasgow.

FitzPatrick, E. 2004 Royal Inauguration in Gaelic Ireland, c.1100-1600: A Cultural Landscape Study. Woodbridge. Boydell Press.

Flanagan, D. 1984 The Christian Impact on Early Ireland: Place-Names Evidence. In Ní Chatháin, P. and Richter, M. (eds.) Ireland and Europe: The Early Church, 25-52. Stuttgart. University Press.

Flood, R. 2009 Aspects of the Irish Hillfort: A Reappraisal in Light of Recent Research in the Upper Slaney Valley. Unpublished MLitt thesis. University College Dublin.

Frag. A.: Fragmentary Annals, CELT: https://celt.ucc.ie//published/T100017/ [last accessed $22^{\text {nd }}$ November 2019]

Gleeson, P. forthcoming Landscapes of Kingship in Early Medieval Ireland. Oxford. Oxford University Press. 
Gleeson, P. 2012 Constructing kingship in Early Medieval Ireland: power, place and ideology. Medieval Archaeology 56, 1-33.

Gleeson, P. 2014 'Assembly and elite culture in late Antique Europe: a case study of Óenach Clochair', Journal of Irish Archaeology 23, 171-87.

Gleeson, P. 2015 Kingdoms, communities, and Óenaig: Irish assembly practices in their northwest European context. Journal of the North Atlantic 8, 33-51.

Gleeson, P. 2017a Luigne Breg and the origins of the Uí Néill. Proceedings of the Prehistoric Society 117C, 1-35.

Gleeson, P. 2017b Gathering the nations: towards an archaeology of assembly in Early Medieval Ireland. In Beglane, F. (ed.) Gatherings: Past and Present, 12-19. Oxford. BAR International Series 2832.

Gleeson, P. and Ó Carragáin, T. 2016 Christianisation in Leinster's royal heartland: an interdisciplinary case study. In Ó Carragáin, T. and Turner, S. (eds.). Making Christian Landscapes in Atlantic Europe: Conversion and Consolidation in the Early Middle Ages, 75-108. Cork. Cork University Press.

Grabowski, K. 1990 The historical overview of Dún Ailinne, Emania 8, 32-6.

Greene, D. 1955 Fingal Rónáin and Other Stories. Medieval and Modern Irish Series 16. Dublin. Dublin Institute for Advanced Studies.

Hogan, E. 1910 Onomasticon Goedelicum. Dublin. Four Courts Press.

Hogg, A., 1975 Hillforts of Britain. London. Hart-Davis, MacGibbon.

Kerr, T. 2007 Early Christian Settlement in North-west Ulster. Dublin. Archaeopress. 
Kristiansen, K. and Larsson, T. 2005 The Rise of Bronze Age Society: Travels, Transmissions and Transformations. Cambridge. Cambridge University Press.

Lacey, B. 2006 Cenél Conaill and the Donegal kingdoms AD 500-800. Dublin. Four Courts Press.

Lynn, C. and McDowell, J. 2011 Deer Park Farms: The Excavation of a Raised Rath in the Glenarm Valley, Co. Antrim. Belfast. The Stationary Office.

M: Annals of the Four Masters, CELT database: https://celt.ucc.ie//published/T100005B/index.html [last accessed 07th April 2020].

Mac Niocaill, G. 1972 Ireland before the Vikings. Dublin. Gill and Macmillan.

MacCotter, P. 2008 Medieval Ireland: Territorial, Political and Economic Divisions. Dublin. Four Courts Press.

MacCotter, P. 2016 Reconstructing the territorial framework for ecclesiastical and secular power structures: a case study of the kingdom of Uí Fáéláin. In Ó Carragáin, T. and Turner, S. (eds.) Making Christian landscapes in Atlantic Europe: conversion and consolidation in the Early Middle Ages, 5574. Cork. Cork University Press.

MacShamhráin, A. 1996 Church and Polity in Pre-Norman Ireland: The Case of Glendalough. Maynooth. An Sagart, Maynooth Monographs 7.

McCormick, F. and Murray, E. 2007 Excavations at Knowth: Knowth and the Zooarchaeology of Early Christian Ireland. Dublin. Royal Irish Academy.

Newman, C. 1998 Reflections on the making of a 'royal site' in early Ireland. World Archaeology 30: The Past in the Past: Reuse of Ancient Monuments, 127-41 
Ó Carragáin, T. 2009 Cemetery settlements and local churches in pre-Viking Ireland in light of comparisons with England and Wales. In Graham-Campbell, J. and Ryan, M. (eds.), Irish/Anglo-Saxon relations before the Vikings. Proceedings of the British Academy 157, 239-61.

Ó Carragáin, T. 2010 From family cemeteries to community cemeteries in Viking Age Ireland? In Corlett, C. and Potterton, M. (ed.) Death and Burial in Early Medieval Ireland in Light of Recent Archaeological Excavations, 217-26. Dublin, Wordwell.

Ó Carragáin, T. 2015a Churches and social power in early medieval Ireland: a case study of Fir Maige In Escalona, J. and Shapland, M. (eds.), Churches and social power in early medieval Europe, 266-312. Brepols. Turnhout.

Ó Cróinín, D. 2005 A New History of Ireland: Prehistoric and Early Ireland. Oxford, Oxford University Press.

O’Brien, M. A. 1962 Corpus genealogiarum Hiberniae, Dublin. Dublin Institute for Advanced Studies.

O'Brien, W. and O'Driscoll J. 2017 Hillforts, Warfare and Society in Bronze Age Ireland. Oxford. Archaeopress.

O'Driscoll, J. 2016 The Baltinglass Landscape and the Hillforts of Bronze Age Ireland. Unpublished PhD Thesis, University College Cork, Ireland.

O'Sullivan, A., McCormick, F., Kerr, T and Harney, L. 2008 Early Medieval Ireland: Archaeological Excavations 1930-2004. EMAP Report 2.1 www.ucd.ie/t4cms/emap_report_2_1_complete.pdf, accessed September 2010.

O'Sullivan, A., McCormick, F., Kerr, T. and Harney, L. 2013 Early medieval Ireland, AD 400-1100: the evidence from archaeological excavations. Dublin. Royal Irish Academy. 
O'Sullivan, J. 2007 The quite landscape: archaeological discoveries on a road scheme in east Galway. In McKeon, J. and O'Sullivan, J. (eds.) 81-100. The Quite Landscape. Dublin. National Roads Authority.

Opie, H., 2004 Ardree (Ardreigh): medieval settlement and graveyard. In Bennett, I. (ed.)

Excavations 2002: summary accounts of archaeological excavations in Ireland, 228 (no. 856). Bray. Wordwell.

O'Toole, P. 1890 History of the Clan O'Tool and other Leinster Septs. Dublin. Gill and Son.

Price, L. 1949a The Place-names of Co. Wicklow III-The Barony of Talbotstown Upper. Dublin. The Dublin Institute for Advanced Studies.

Price, L. 1949b Place-name study as applied to history. Journal of the Royal Society of Antiquaries of Ireland 79 (1), 26-38.

Radner, J. (ed.) 1976 Fragmentary Annals of Ireland. Dublin. Dublin Institute of Advanced Studies.

Raftery, B. 1994 Pagan Celtic Ireland. London. Thames and Hudson.

Ryan, M. 1973 The excavation of a Neolithic burial mound at Jerpoint West, Co. Kilkenny. Proceedings of the Royal Irish Academy 73 (C), 107-27.

Semple, S. 2013 Perceptions of the prehistoric in Anglo-Saxon England: ritual, religion and rulership. Oxford. Oxford University Press.

Smith, G. 1990 Excavations at Ham Hill, 1983. Proceedings of the Somerset Archaeological Nature History Society 134, 27-47.

Smyth, A. P. 1972 The earliest Irish annals: their first contemporary entries, and the centres of recording. Proceedings of the Royal Irish Academy 72 (C), 1-48. 
Smyth, A. P. 1974 The Húi Néill and the Leinstermen in the Annals of Ulster, 431-516 AD', Études Celtiques 14, 121-43.

Smyth, A. 1982 Celtic Leinster: Towards an Historical Geography of Early Irish Civilization AD 5001600. Dublin. Irish Academic Press.

Smyth, A. 1994 Kings, saints and sagas. In Hannigan, K. and William, N. (eds.), Wicklow, History and Society: Interdisciplinary Essays on the History of an Irish County, 41-112. Dublin. Geography Publications.

Stout, G. and Stout, M. 2008 Excavation of a Secular Cemetery at Knowth Site M, Co. Meath and Related Sites in North Leinster. Bray. Wordwell.

Stokes, W. (ed and trans) 1892 The Bóruma. Revue Celtique 13. 31-124; 299-300.

Stokes, W. (ed and trans) 1895 The prose tales in the Rennes dindshenchas. Revue Celtique 16, 31$83 ; 135-167 ; 269-312,468$.

Stout, M. 2017 Early Medieval Ireland: 431-1169. Dublin. Wordwell.

Swift, C. 2006 Brigid, Patrick, and the kings of Kildare, A.D. 640-850' In Nolan, W. and McGrath, T. (eds.), Kildare: history and society, 97-128. Dublin. Geography Publications.

T: Annals of Tighernach, CELT database: https://celt.ucc.ie/published/T100002A/index.html [last accessed 07th April 2020].

Waddell, J., Fenwick, J. and Barton, K. 2009 Rathcroghan: Archaeological and Geophysical Survey in a Ritual Landscape. Dublin. Wordwell.

Wailes, B. 1982 The Irish 'royal sites' in history and archaeology. The Welsh History Review, 1-29. 
Warner, R. 1988 The archaeology of early historic Irish kingship. In O'Driscoll, S. T. and Nieke, M. (eds.) Power and Politics in Early Medieval Britain and Ireland, 47-68. Edinburgh. Edinburgh University Press,

Wheeler, M. 1953 An Early Iron Age beach-head at Lulworth, Dorset, Antiquity 33, 1-13.

\section{List of Figures}


Figure 1: Location map of sites mentioned in text.

Figure 2: Brusselstown Ring from the summit of Spinans Hill 1.

Figure 3: The Spinans Hill enclosure complex taken from the summit of Keeden Mountain.

Figure 4: Photogrammetry Survey of the Spinans Hill enclosure complex.

Figure 5: Spinans Hill enclosing elements.

Figure 6: Cumulative viewshed analysis of the Glen of Imaal.

Figure 7: GPS survey of Kilranelagh Hill.

Figure 8: Photogrammetry survey of the Castleruddery mound, at the northern base of Spinans Hill.

Figure 9: Distribution map of recorded churches and baronies surrounding Dún Bolg.

Figure 10: Magnetic gradiometry survey at Rathmoon cemetery settlement.

Figure 11: Interpretation of the magnetic gradiometry survey at Rathmoon cemetery settlement. 


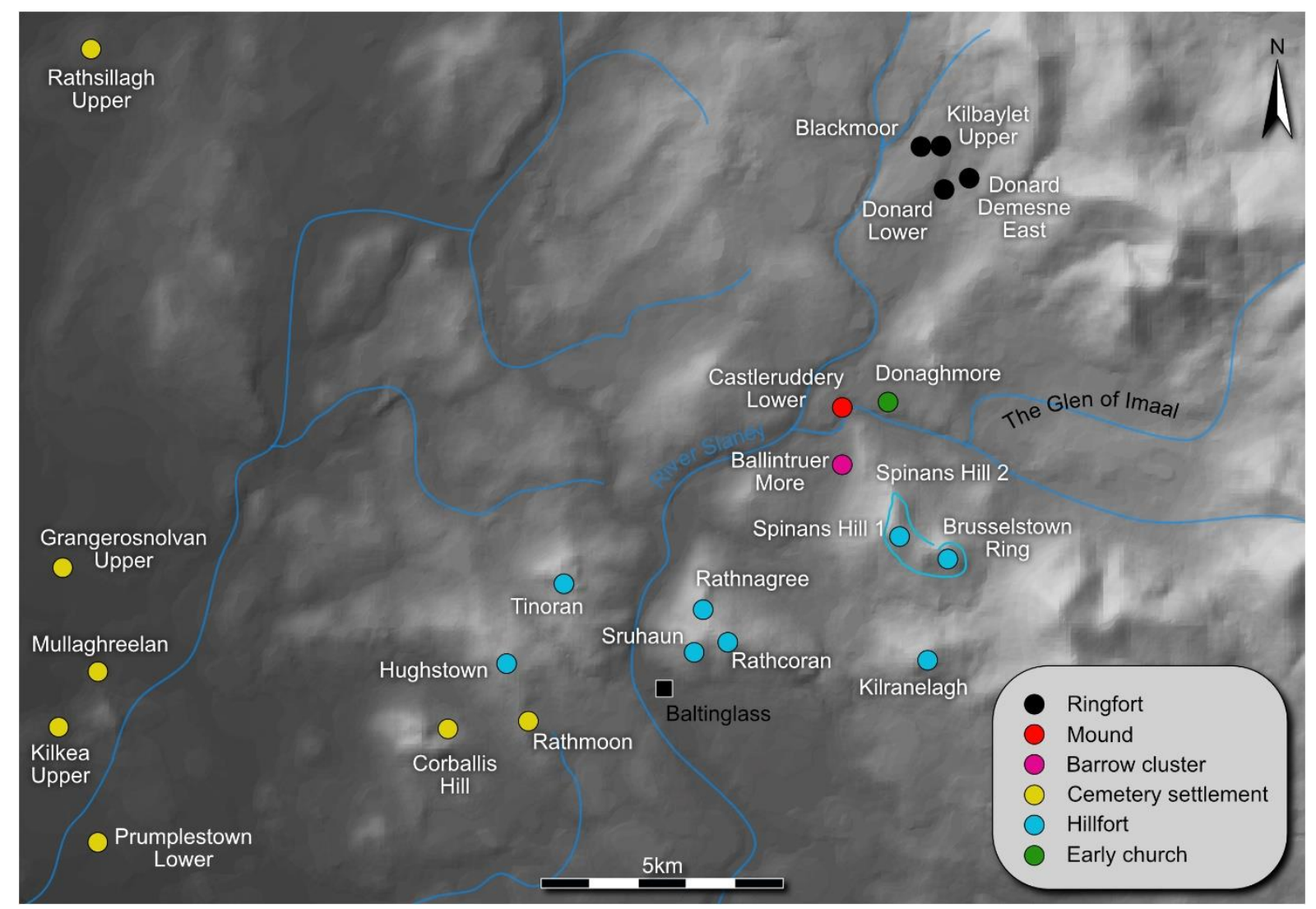

Figure 1 


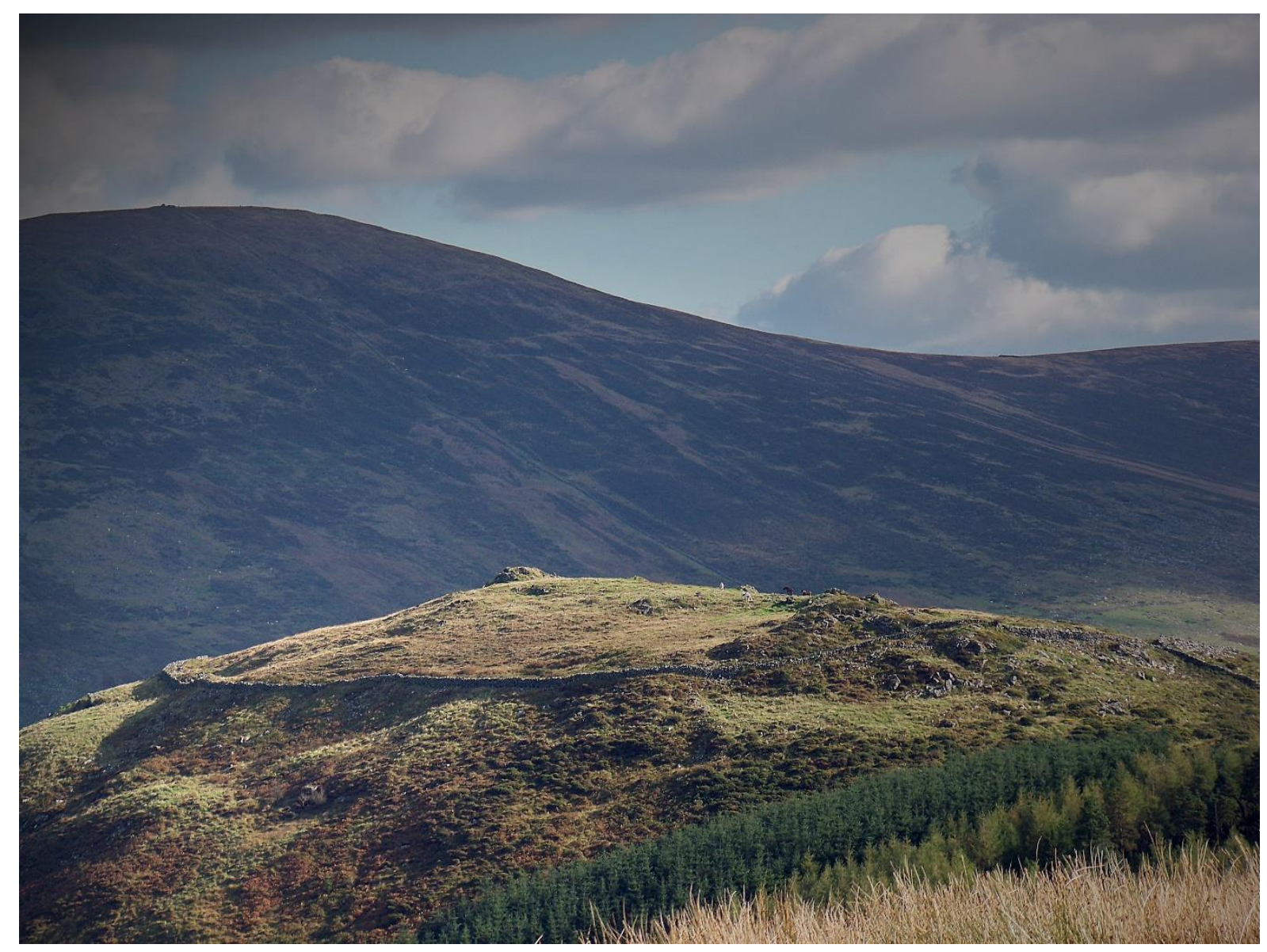

Figure 2 


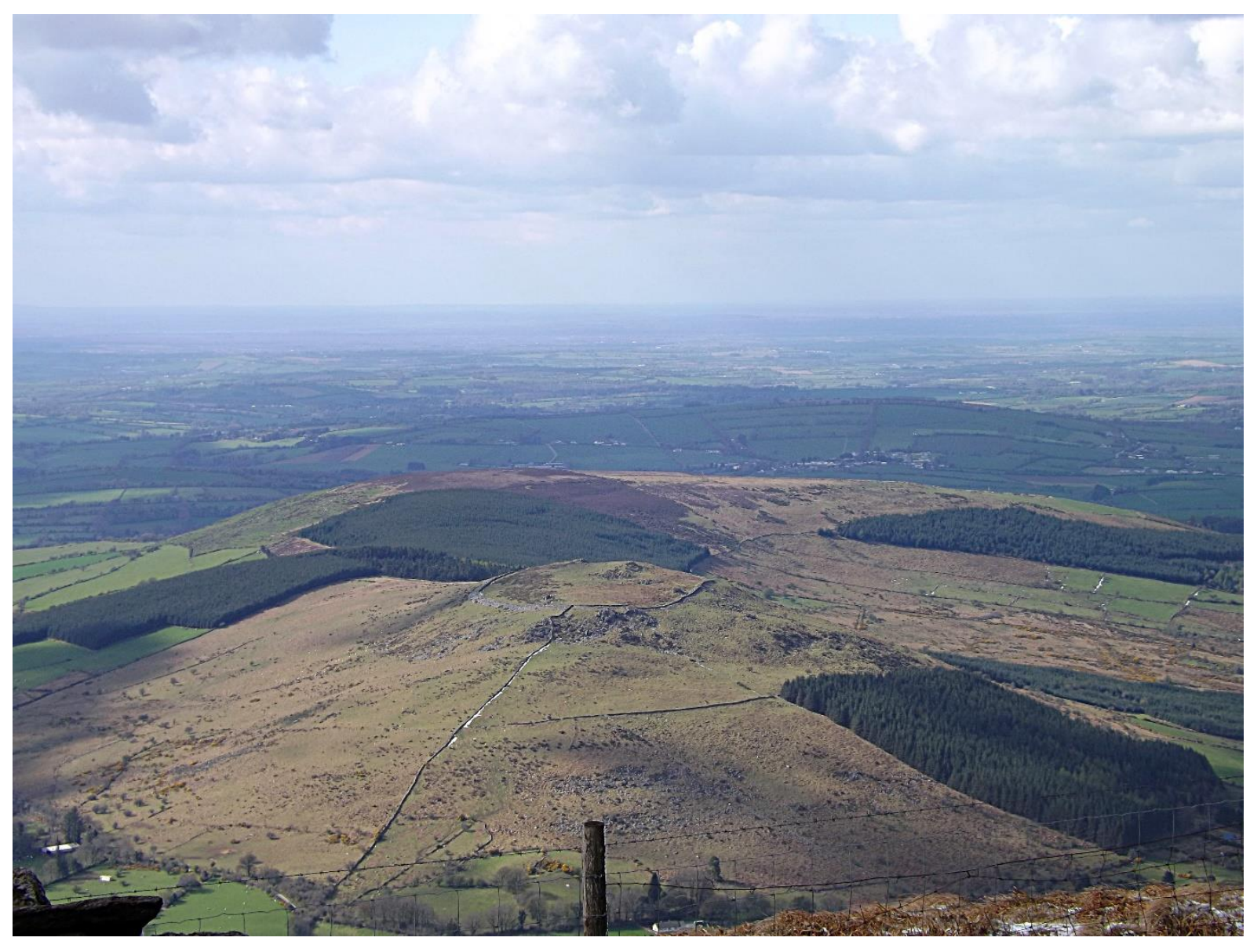

Figure 3 


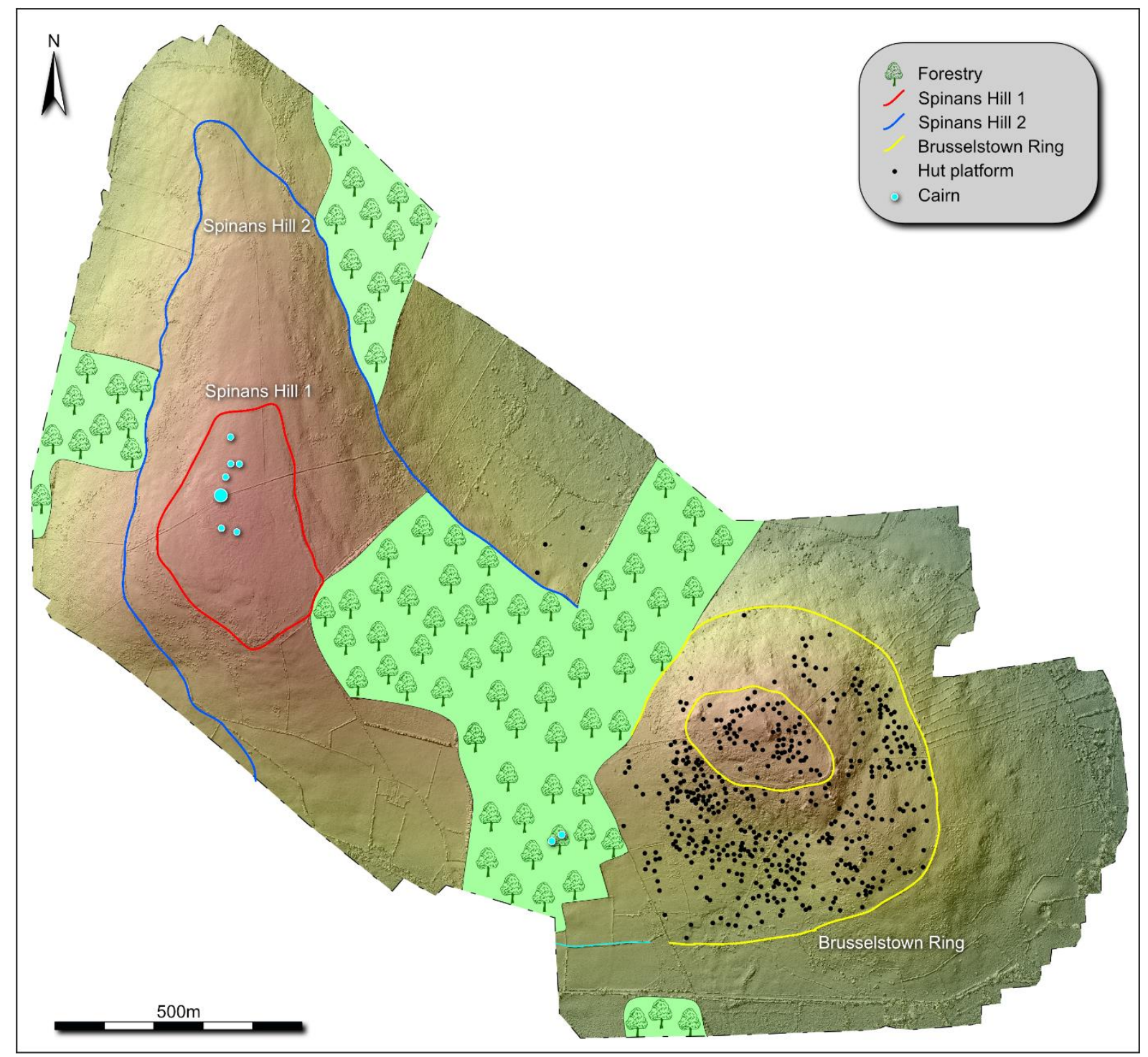

Figure 4 


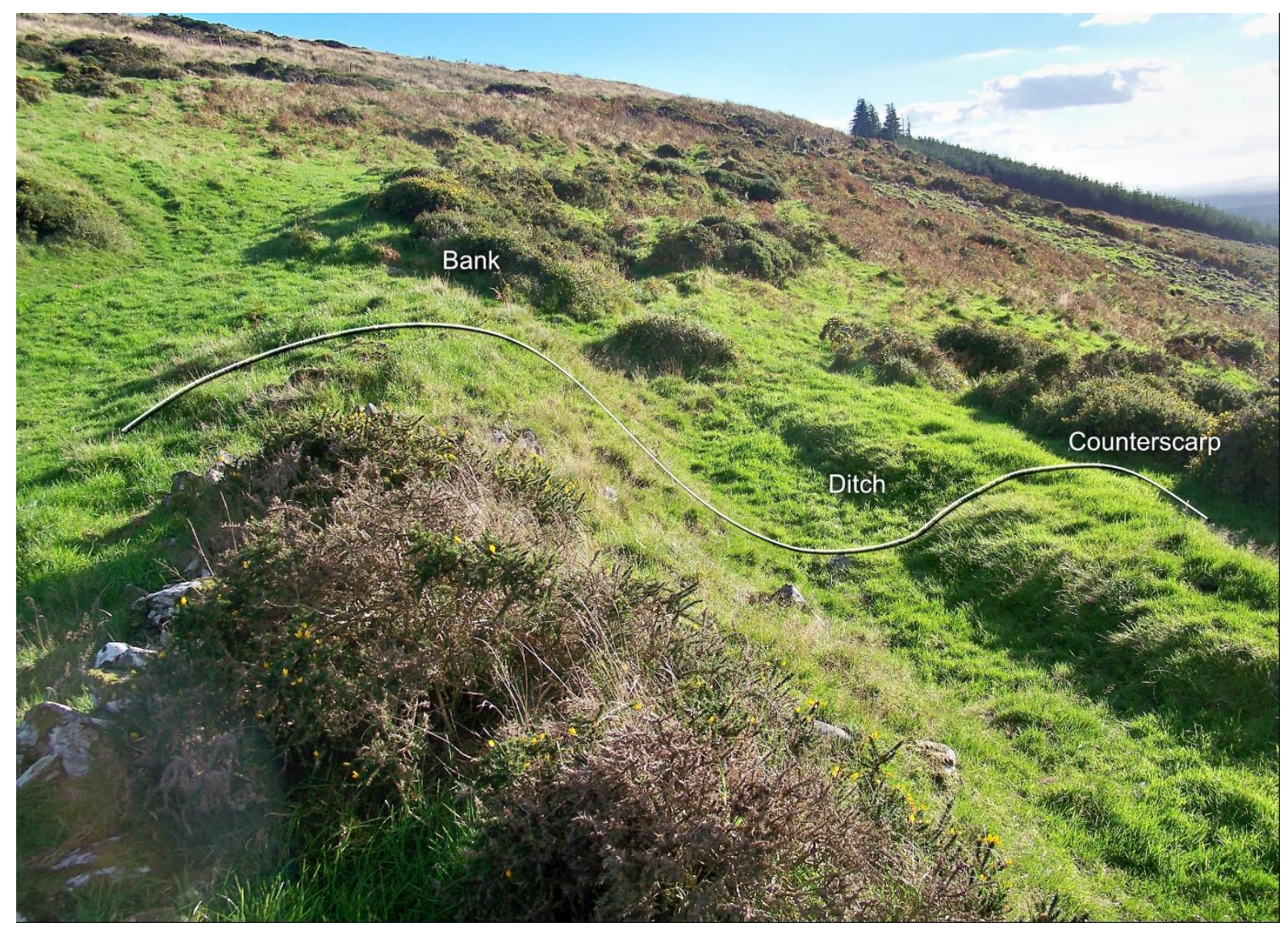

Figure 5 


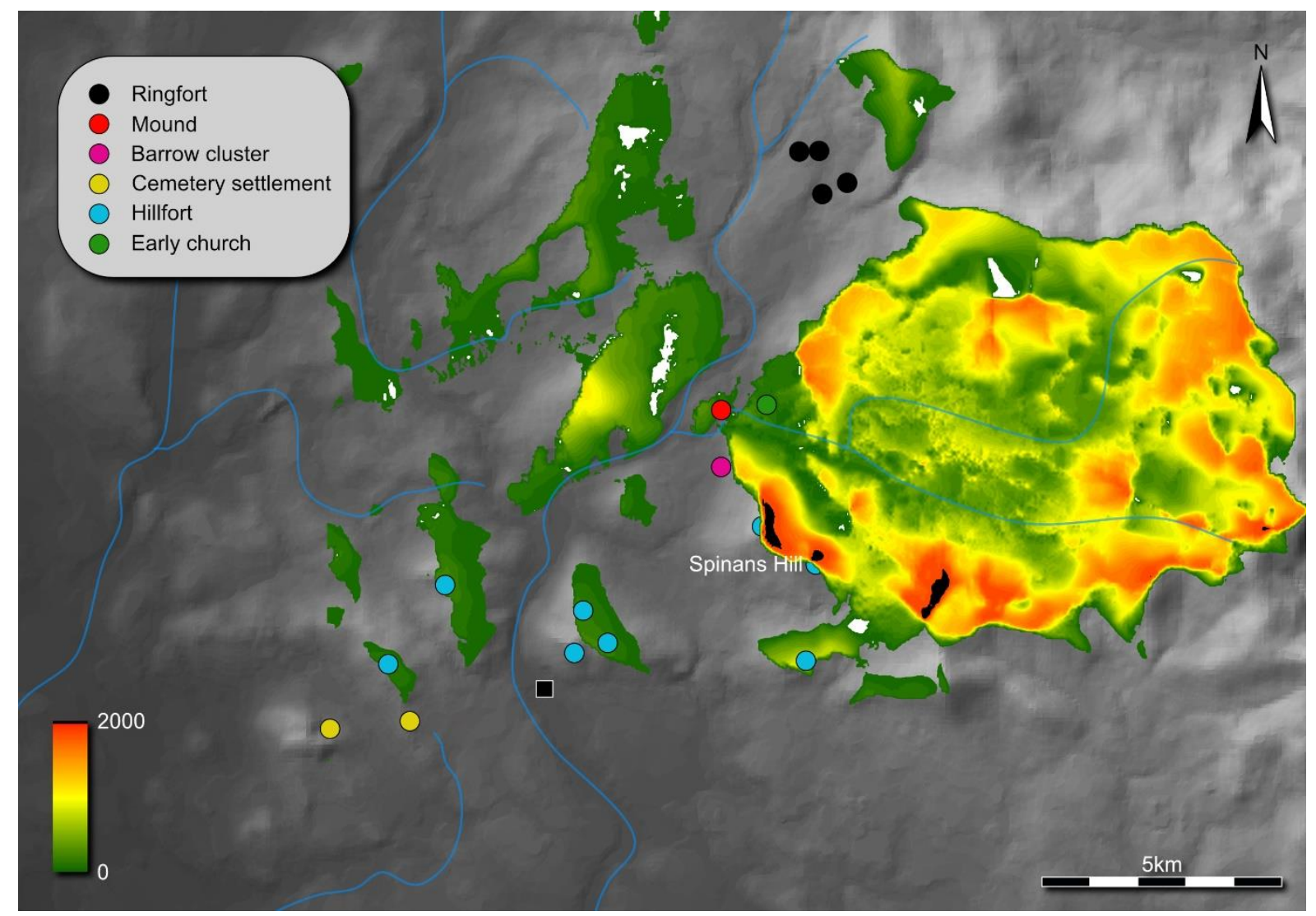

Figure 6 


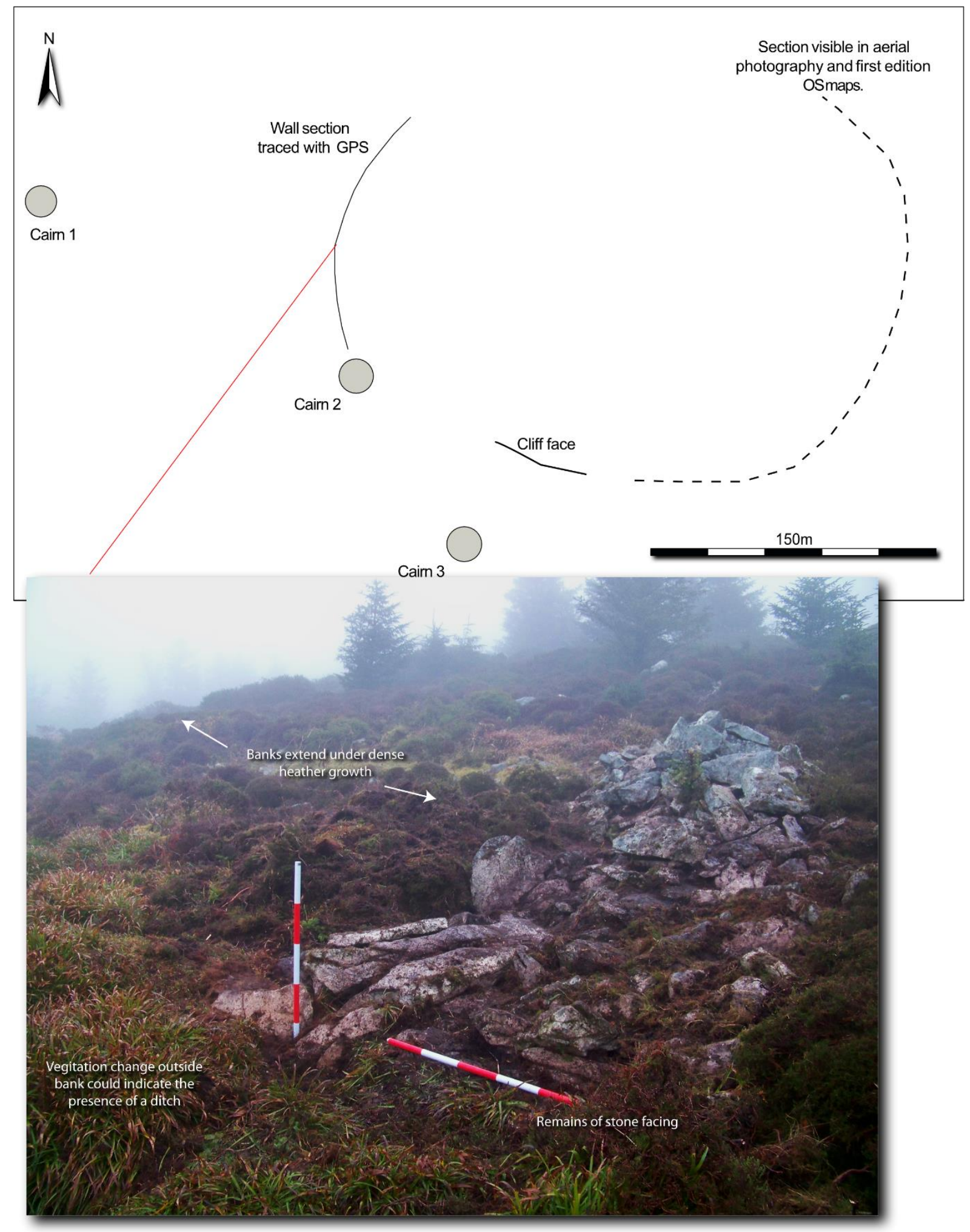

Figure 7 

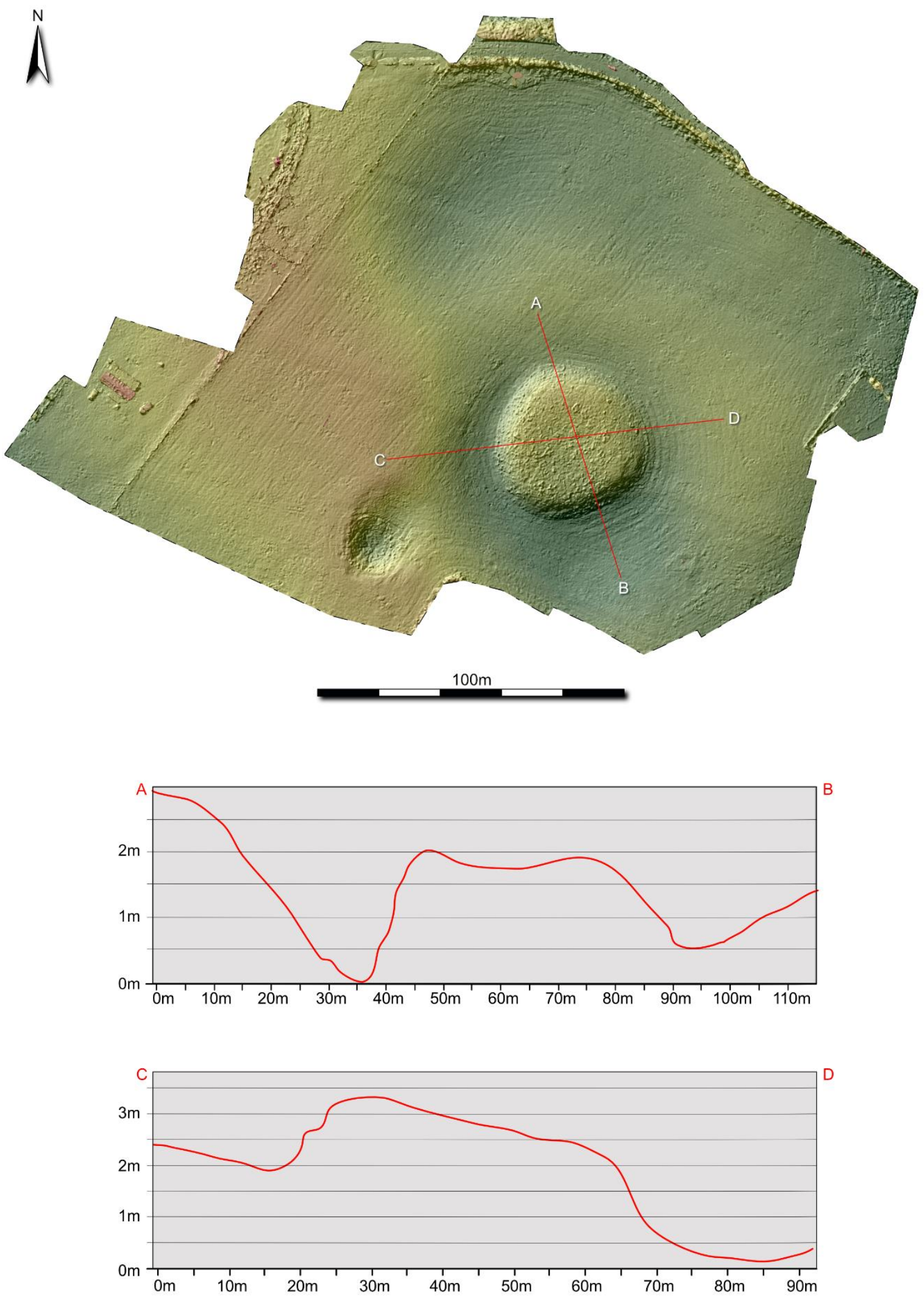

Figure 8 


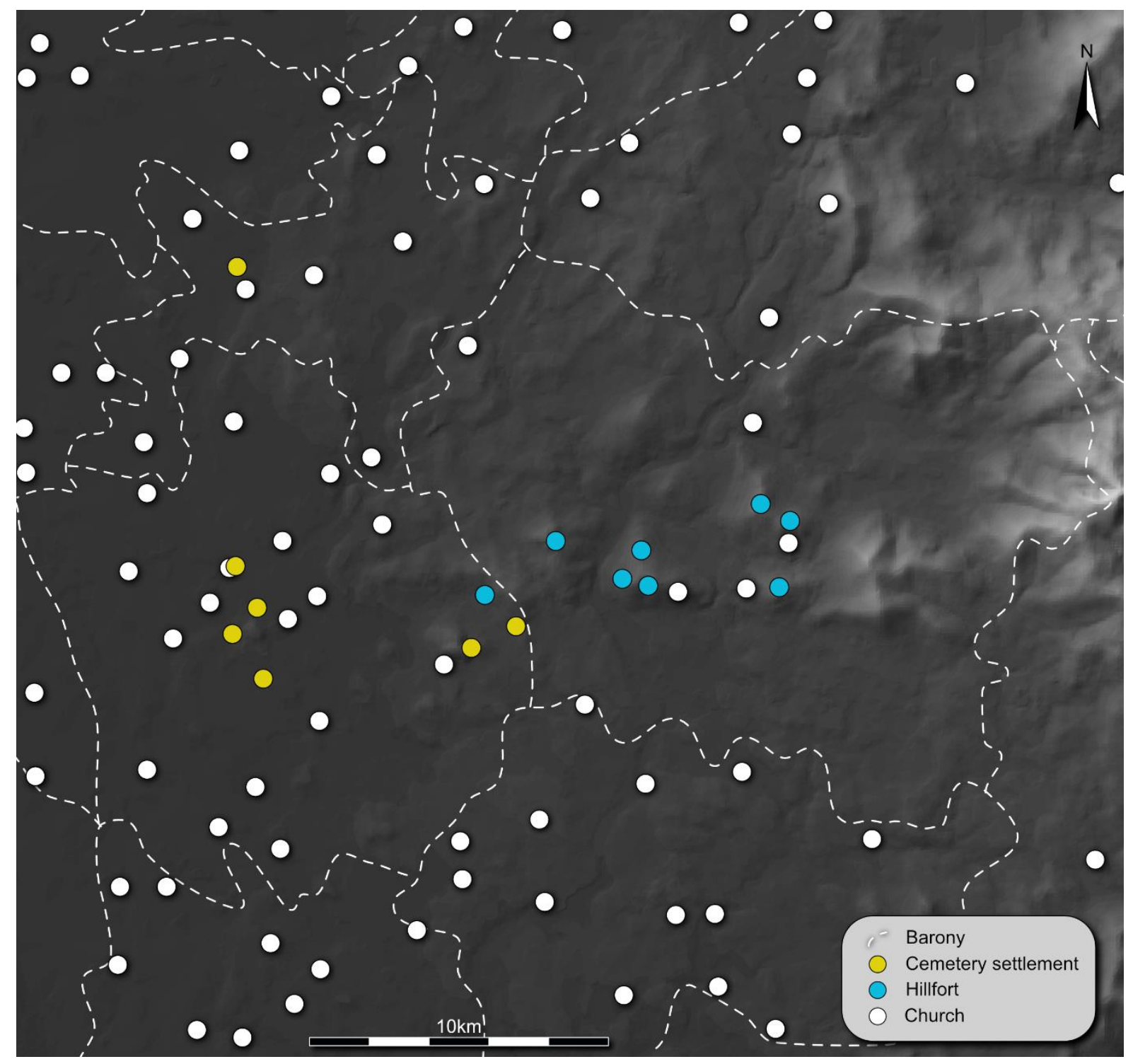

Figure 9 


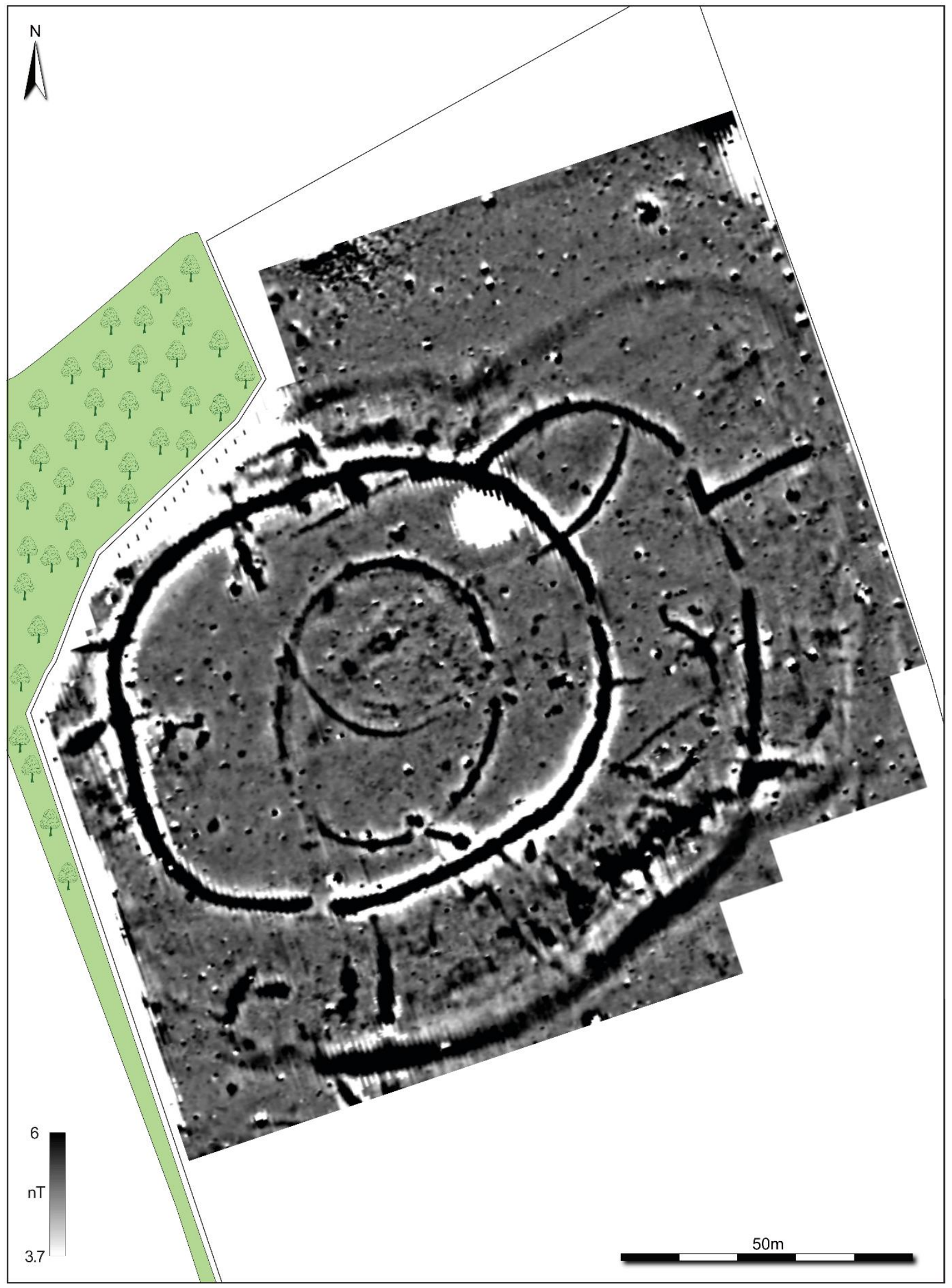

Figure 10 


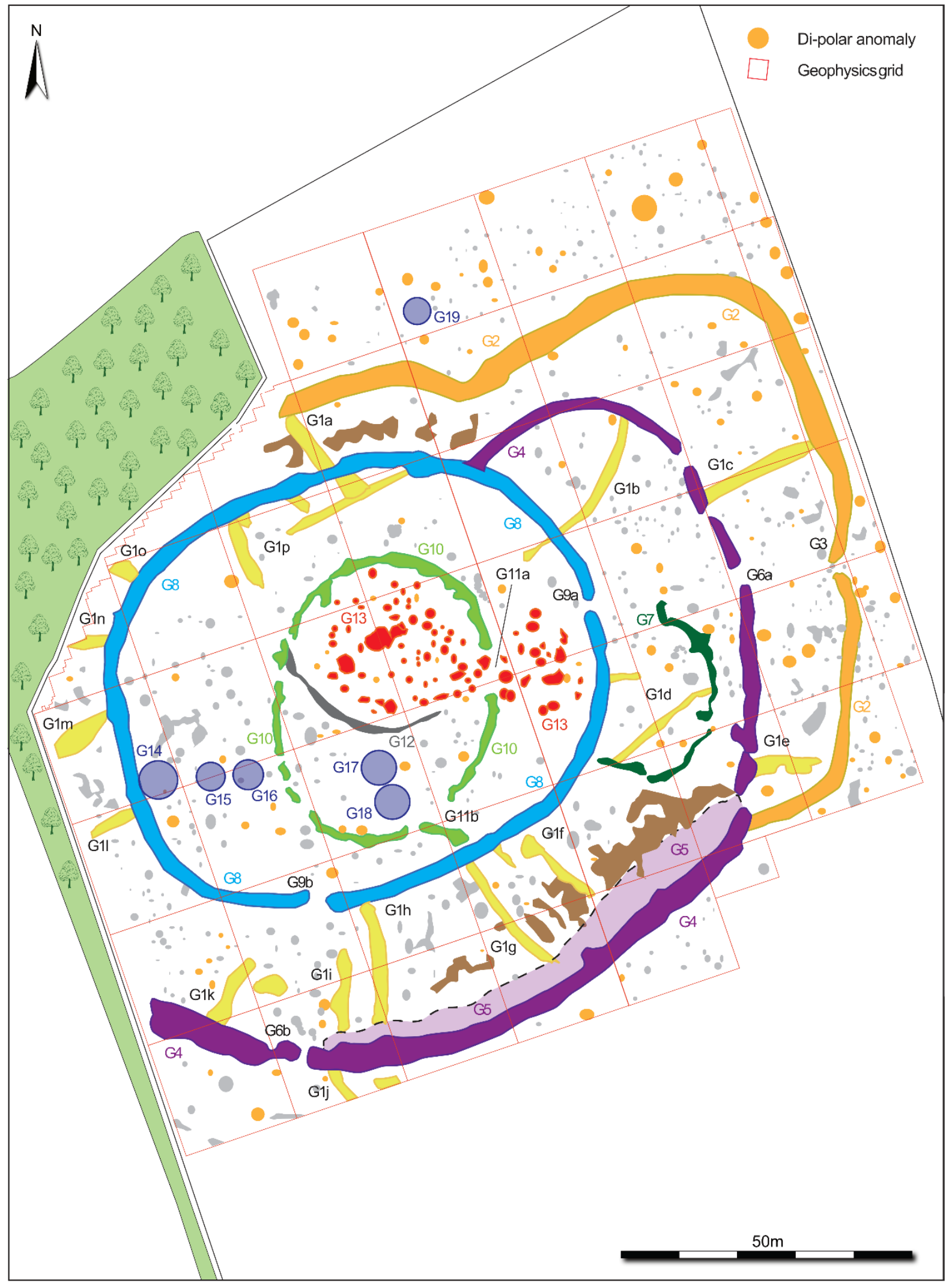

Figure 11 